\title{
Succession and fate of the spring diatom bloom in Disko Bay, western Greenland
}

\author{
Michael Dünweber ${ }^{1,4}$, Rasmus Swalethorp ${ }^{1,4}$, Sanne Kjellerup ${ }^{1,4}$, \\ Torkel Gissel Nielsen ${ }^{1,4, *}$, Kristine Engel Arendt ${ }^{2}$, Morten Hjorth ${ }^{1}$, \\ Kajsa Tönnesson ${ }^{3}$, Eva Friis Møller ${ }^{1}$ \\ ${ }^{1}$ National Environmental Research Institute, Department of Marine Ecology, University of Aarhus, Frederiksborgvej 399, \\ 4000 Roskilde, Denmark \\ ${ }^{2}$ Greenland Climate Research Centre, Greenland Institute of Natural Resources, Kivioq 3, Po Box 570, 3900 Nuuk, Greenland \\ ${ }^{3}$ Department of Marine Ecology — Göteborg, University of Gothenburg, Box 461, 40530 Göteborg, Sweden \\ ${ }^{4}$ Section for Oceanecology and Climate, National Institute of Aquatic Resources, Technical University of Denmark, \\ Kavalergården 6, 2920 Charlottenlund, Denmark
}

\begin{abstract}
Phytoplankton and copepod succession was investigated in Disko Bay, western Greenland from February to July 2008. The spring phytoplankton bloom developed immediately after the breakup

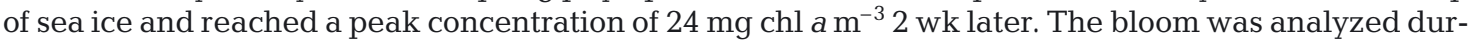
ing 3 phases: the developing, the decaying, and the post-bloom phases. Grazing impact by the copepod community was assessed by 4 methods; gut fluorescence, in situ faecal pellet production, and egg and faecal pellet production from bottle incubations. Calanus spp. dominated the mesozooplankton community. They were present from the initiation of the bloom but only had a small grazing impact on the phytoplankton. Consequently, there was a close coupling between the spring phytoplankton bloom and sedimentation of particulate organic carbon (POC). Out of $1836 \pm 180 \mathrm{mg} \mathrm{C} \mathrm{m}^{-2} \mathrm{~d}^{-1}$ leaving the upper $50 \mathrm{~m}$, $60 \%$ was phytoplankton based carbon (PPC). The composition and quality of the sedimenting material changed throughout the bloom succession from PPC dominance in the initial phase with a POC/PON ratio close to 6.6 to a dominance of amorphous detritus with a higher POC/PON ratio $(>10)$ in the postbloom phase. The succession and fate of the phytoplankton spring bloom was controlled by nitrogen limitation and subsequent sedimentation, while grazing-mediated flux by the Calanus-dominated copepod community played a minor role in the termination of the spring bloom of Disko Bay.
\end{abstract}

KEY WORDS: Spring bloom · Calanus spp. · Grazing · Faecal pellets · Sedimentation · Arctic Greenland Resale or republication not permitted without written consent of the publisher

\section{INTRODUCTION}

The spring phytoplankton bloom is a key event in high-latitude marine ecosystems, responsible for fueling high secondary production. It is triggered by the break-up of sea ice, combined with a warming and freshening of the surface layer stratifying the water column. The bloom is characterized by a short and pronounced growth peak of diatoms that depletes the surface layer of nitrate (Andersen 1981) and subsequently sediments (Nielsen \& Hansen 1995, Poulsen \& Reuss 2002).

Sedimentation of phytoplankton from the euphotic zone is the principal mechanism in transport of organic material to benthic communities. Transport occurs directly as intact cells or indirectly as faecal pellets from pelagic grazers, aggregates, and amorphous detritus (Turner 2002, De La Rocha \& Passow 2007). During its transit to the sea bed, the organic material is modified by the pelagic heterotrophs in a way that 
influences its quantity and quality as a carbon source for the benthic community (Kiørboe et al. 1996, Kiørboe 1998, Wassmann 1998, Turner 2002, Riser et al. 2008).

Grazing is a key process that reduces the sedimentation of phytoplankton while simultaneously accelerating the sedimentation through production of fast-sinking faecal pellets (Juul-Pedersen et al. 2006). However, a large portion of the faecal pellets may be retained in the water column due to grazing, disintegration, and remineralisation (Noji et al. 1991, Riser et al. 2002, 2007, Turner 2002, Reigstad et al. 2008). Copepods often only graze a minor fraction of the spring phytoplankton bloom, because their longer generation time compared to that of phytoplankton limits them in numerically responding to the bloom (Kiørboe 1998). This results in a high sedimentation of ungrazed phytoplankton. In Arctic areas however, where overwintering stocks of copepods like Calanus exist, the copepod grazing impact on the bloom dynamics may be larger, depending on whether ascending Calanus match the spring phytoplankton bloom or not (Bathmann et al. 1990, Wassmann 1998, Wassmann et al. 2004, 2006).

The pelagic food web structure and production in Disko Bay, western Greenland, has been intensively investigated since the early 1990s (Nielsen \& Hansen 1995). The original focus was mainly on baseline descriptions of composition and trophodynamics of the pelagic food webs (Levinsen et al. 2000a, Madsen et al. 2001, Madsen et al. 2008b). Few studies have considered the sedimentation of organic matter from the surface layer in this region (Juul-Pedersen et al. 2006, Sejr et al. 2007), and investigations resolving the contribution from the spring bloom are lacking. A match between copepod ascent to the surface and the spring phytoplankton bloom would lead to a large grazing impact on the phytoplankton biomass, while a mismatch would result in a larger contribution of ungrazed phytoplankton to the sedimentation.

Over the last decades, the physical forcing of the plankton succession in Disko Bay has changed. Recently an acceleration of the melt water input from the Jakobshavn Isbræ glacier to the bay has been documented (Holland et al. 2008), which, in combination with the general reduction of the sea ice cover (IPPC 2008), potentially impacts stratification, light conditions for the plankton, and consequently the timing and succession of the lower trophic levels of the food chain. Therefore baseline knowledge of carbon flow during the short and pronounced spring diatom bloom needs to be acquired if the ecological impact of future environmental disturbances associated with climate change and increased human activities (e.g. oil exploration) is to be be understood. The aim of the present study was to investigate the succession and fate of the spring diatom bloom in Disko Bay, with emphasis on evaluating the role of sedimentation versus grazing impact by the Calanus dominated zooplankton community.

\section{MATERIALS AND METHODS}

Study site. The study site was located in the Disko Bay off Qeqertarsuaq, western Greenland (Fig. 1). Due to land-connected sea ice coverage during winter, 2 sampling sites were combined. At the first site in winter (21 February to 23 March 2008), sampling was conducted through a hole in the ice at ca. 65 to $160 \mathrm{~m}$ depth approximately 0.5 nautical mile (n mile) south of Qeqertarsuaq $\left(69^{\circ} 14^{\prime} \mathrm{N}, 53^{\circ} 29^{\prime} \mathrm{W}\right)$. In spring and summer (9 April to 18 July), sampling was done at a monitoring station $1 \mathrm{n}$ mile south from Qeqertarsuaq $\left(69^{\circ} 14^{\prime} \mathrm{N}, 53^{\circ} 23^{\prime} \mathrm{W}\right)$ (Fig. 1) at $300 \mathrm{~m}$ depth, onboard RV 'Porsild' (Arctic station, University of Copenhagen) and 'Maja S' (Finn Steffens, Qeqertarsuaq).

Sampling. Sampling was carried out between 10:00 and 17:00 h. Vertical profiles of water temperature and salinity were measured down to $150 \mathrm{~m}$ during winter and down to $250 \mathrm{~m}$ during spring and summer, using a

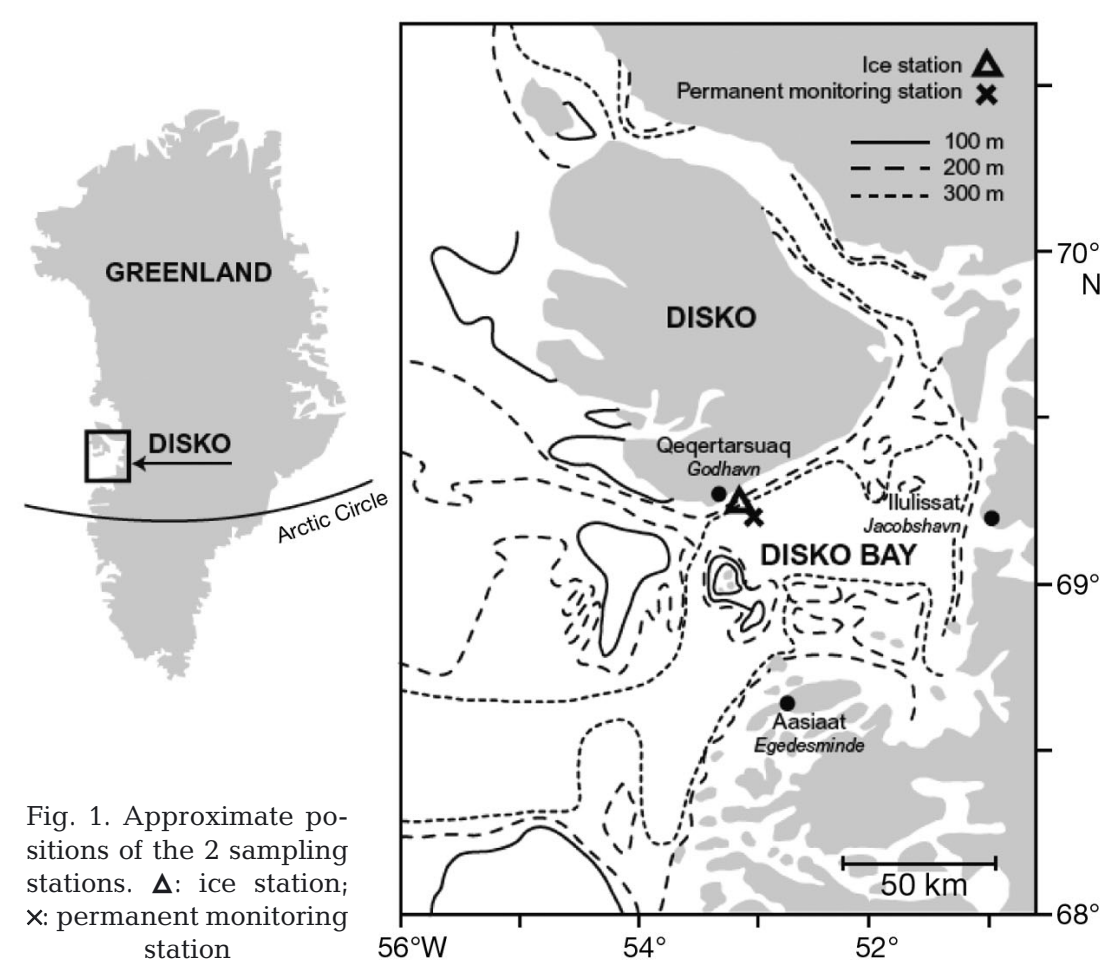


Seabird SBE25-01-CTD. Salinity measurements were calibrated against salinity samples taken approximately once a month $(\mathrm{n}=4)$ throughout the study phase, and analyzed on an 8410-Portasal salinometer (Guildline).

Samplings for chemical and biological variables were taken at 6 depths $(1,20,50,75,100$, and $150 \mathrm{~m})$ using a 101 Niskin bottle. Two additional depths (200 and $250 \mathrm{~m}$ ) were included after ship-based sampling was initiated. Chlorophyll a (chl a), particulate organic carbon (POC), and particulate organic nitrogen (PON) samples were siphoned directly to 101 acid cleaned dark carboys and kept in the dark until filtering (max. $1 \mathrm{~h}$ after arrival to laboratory). Inorganic nutrient samples (phosphate, nitrate, ammonia, and silicate) were immediately frozen $\left(-30^{\circ} \mathrm{C}\right)$ for later analysis on a Skalar autoanalyser (Breda), following the procedures of Grasshoff (1976). Nutrient sample precisions were $0.06,0.1,0.3$, and $0.2 \mu \mathrm{M}$ for phosphate, nitrate, ammonia, and silicate, respectively. For analysis of size-fractionated chl a and phaeopigments (phaeo), triplicate subsamples (200 to $500 \mathrm{ml}$ ) were filtered onto Whatman GF/F filters $(0.7 \mu \mathrm{m})$ and mesh nets $(10 \mu \mathrm{m}$ and $50 \mu \mathrm{m})$. The filters were extracted in $5 \mathrm{ml} 96 \%$ ethanol overnight (Jespersen \& Christoffersen 1987), and pigments were measured on a TD-700 fluorometer (Turner) and calibrated against a chl a standard before and after acidification (Yentsch \& Menzel 1963).

Samples of POC and PON were collected at 3 depths $(1,20,50 \mathrm{~m})$ from the ice station, with an additional fourth depth $(100 \mathrm{~m})$ from 30 April onwards. Samples (0.7 to $4.5 \mathrm{l}$ ) were filtered onto pre-combusted $\left(400^{\circ} \mathrm{C}\right.$ for $2 \mathrm{~h}$ ) Whatman GF/F filters, which were stored frozen $\left(-30^{\circ} \mathrm{C}\right)$ until analysis on a CHNS Automatic Elemental Analyzer (EA 1110, CE Instruments) after drying at $60^{\circ} \mathrm{C}$ for $24 \mathrm{~h}$. POC was divided into 3 fractions: chl a-based POC (PPC), faecal pellet-based POC (FPC), and amorphous detritus-based POC (amorphous detritus). PPC was estimated from a regression line between chl $a$ and water column POC (see Eq. 7 in 'Results'). The amorphous detritus fraction was estimated by subtracting PPC and FPC from POC.

Mesozooplankton. During sampling from the ice, mesozooplankton was collected using a modified WP-2 net $(45 \mu \mathrm{m})$ equipped with a closing mechanism (Hydrobios). Samples were collected in 3 depth strata (0-50, 50-100, and 100-150 m). During ship-based sampling, mesozooplankton was collected with a multinet $(50 \mu \mathrm{m})$ equipped with a flow meter (Multinet, Hydrobios type midi), and 2 additional depth strata (150200 and 200-250 m) were included. In addition to the seasonal study one diurnal investigation with sampling every $6 \mathrm{~h}$ was conducted from 29 April at 12:00 h to 30 April 30 at 12:00 h. Samples were immediately preserved in buffered formalin ( $5 \%$ final concentration) for later analyses. Biomass values of the different copepod species were calculated based on measurements of prosome length, and length/weight relationships. Two regressions for Calanus spp. were established for biomass calculations: one applicable prior to and during the phytoplankton bloom until 4 May, and another from 9 May onwards (R. Swalethorp et al. unpubl.). Regressions for the remaining copepod species were taken from the literature (Satapoomin 1999, Thor et al. 2005, and references therein).

Gut fluorescence. Gut fluorescence were measured on females of Calanus finmarchicus, C. glacialis, and C. hyperboreus collected using a WP-2 net towed at $0.5 \mathrm{~m} \mathrm{~s}^{-1}$ from $100 \mathrm{~m}$ to the surface. A subsample of the cod-end was immediately concentrated on a piece of $100 \mu \mathrm{m}$ plankton gauze and frozen to $-40^{\circ} \mathrm{C}$ by freeze spraying (75 super, Kontakt Chemie) and then stored frozen $\left(-30^{\circ} \mathrm{C}\right)$. Females of C. hyperboreus were gently collected from the rest of the cod-end and transferred individually into vials containing $5 \mathrm{ml} 96 \%$ ethanol and kept dark for later analysis. The full operation took less than $5 \mathrm{~min}$. In the laboratory, samples of C. glacialis and $C$. finmarchicus were gently thawed under dim light, diluted with $0.2 \mu \mathrm{m}$ ice-cold filtered seawater, and triplicate pools of $C$. finmarchicus $(\mathrm{n}=5)$ and C. glacialis ( $\mathrm{n}=3$ ) were extracted in $5 \mathrm{ml} 96 \%$ ethanol. All samples were analyzed for chl a and phaeo as described above. Background values of C. finmarchicus $(\mathrm{n}=45), C$. glacialis $(\mathrm{n}=25)$, and C. hyperboreus ( $\mathrm{n}=20$ ) were estimated after incubation for $24 \mathrm{~h}$ in 0.2 $\mu \mathrm{m}$ filtered seawater that was renewed after $12 \mathrm{~h}$. Background values were subtracted from all the Calanus spp. gut fluorescence measurements.

Ingestion rate $\left(I ; \mu \mathrm{g}\right.$ individual $\left.{ }^{-1} \mathrm{~d}^{-1}\right)$ was calculated using the following equation (modified from Harris et al. 2000)

$$
I=K \times G \times 60 \times 24
$$

where $K$ is the instantaneous gut defecation rate constant $\left(\mathrm{min}^{-1}\right)$ and $G$ is the gut pigment ( $\mu \mathrm{g}$ chl a). The gut pigment was converted to carbon by application of a conversion factor of 29.9 measured during the present investigation. Instantaneous gut defecation values of 0.032 for C. finmarchicus (Maar et al. 2002), 0.017 for C. glacialis, and 0.015 for C. hyperboreus (Hansen et al. 1990) were used and corrected to in situ temperature by applying a $Q_{10}$ value of 2.8 (Hansen et al. 1997). Specific ingestion rate $\left(\% \mathrm{~d}^{-1}\right)$ was calculated using in situ carbon contents of the 3 Calanus spp. (R. Swalethorp et al. unpubl.).

In situ faecal pellet production. Faecal pellet production of the copepod community was measured in short time incubations during ship-based sampling from 23 April to 9 June. Copepods were collected using a WP-2 net $(200 \mu \mathrm{m})$ from $100 \mathrm{~m}$ to the surface. Subsamples of the cod-end were immediately distrib- 
uted into 8 fecatrons made of clear PVC (polyvinyl chloride) tubes (inner diameter $8 \mathrm{~cm}$, height $40 \mathrm{~cm}$ ) filled with $45 \mu \mathrm{m}$ filtered surface water. One additional subsample was immediately fixed in $2 \%(\mathrm{v} / \mathrm{v})$ acidic Lugol's solution and served as a start sample. Four fecatrons were equipped with a $200 \mu \mathrm{m}$ and 4 with a $400 \mu \mathrm{m}$ false mesh bottom. The procedure from sampling of copepods to incubation start took less than $5 \mathrm{~min}$. Concentrations in the fecatrons were between 20 and 385 copepods $\mathrm{l}^{-1}$, and they were incubated for 1 to $2.5 \mathrm{~h}$ in a $100 \mathrm{l}$ container cooled with surface water. Present copepod predators (primarily Sagitta spp. and Pareuchaeta sp.) were removed before the start of the experiment. At the end of the incubations the samples were preserved with $2 \%(\mathrm{v} / \mathrm{v})$ acidic Lugol's solution. In the laboratory, faecal pellets and copepods were concentrated on a $20 \mu \mathrm{m}$ sieve and counted and measured using a stereo light microscope (Olympus SZ40, $40 \times$ magnification for faecal pellets and $20 \times$ for copepods). The dimensions of maximum 30 faecal pellets and 60 copepods were measured and the rest were counted. Faecal pellet measurements and counting criteria were determined, so that the faecal pellets had to be a minimum of $3 \times$ longer than wide. Faecal pellet volume was calculated assuming cylinder shape. FPC was estimated applying a volume to carbon conversion

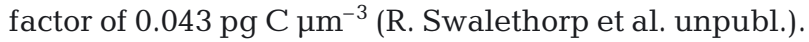
Copepod carbon content was calculated from a combined length/weight regression of Calanus finmarchicus and C. glacialis in the 2 time series as described above (R. Swalethorp et al. unpubl.).

Specific faecal pellet production rate ( $\mathrm{SPP}, \mu \mathrm{g} \mathrm{C}_{\text {pellet }} \mu \mathrm{g}$ $\mathrm{C}^{-1}{ }_{\text {cop }} \mathrm{d}^{-1}$ ) was calculated using the following equation:

$$
\mathrm{SPP}=\mathrm{FPC}_{\text {prod }} /\left(\mathrm{C}_{\mathrm{cop}} \times t\right)
$$

where $\mathrm{FPC}_{\text {prod }}$ is the carbon content of the faecal pellets produced ( $\mu \mathrm{g}_{\text {pellet }}$ ) during the experiment. $\mathrm{C}_{\mathrm{cop}}$ is the biomass of the copepods $\left(\mu \mathrm{g} \mathrm{C}_{\mathrm{cop}}\right.$ ), and $t$ is the duration of the experiment in days. Specific ingestion rate $\left(\% \mathrm{~d}^{-1}\right)$ was calculated assuming an assimilation efficiency of $68.2 \%$ (Conover 1966).

Sedimentation. Sedimentation measurements were conducted from 23 April to 9 June using free-floating sediment traps fitted on a buoy $\left(0.5 \mathrm{~m}^{3}, 75 \mathrm{~kg}\right.$ buoyancy) and moored with a weight $(20 \mathrm{~kg})$ to reduce water resistance and upward drift. The sediment traps (KC Denmark) consisted of 2 parallel acrylic cylinders mounted in a gimballed frame equipped with steering fins and pivot joints to ensure a vertical position perpendicular to the current. The traps had an internal diameter of $0.052 \mathrm{~m}$ with an aspect ratio (height:diameter) of 6.35 . The sediment traps were deployed at 20,50, and $100 \mathrm{~m}$, with an average deployment time of $5.35 \pm 0.1 \mathrm{~h}(10: 00$ to 16:00 h). During deployment, the sediment traps did not drift more than $1 \mathrm{n}$ mile away from the sampling position, except on one occasion where tracking of the traps was temporarily interrupted and deployment time was $24 \mathrm{~h}$ (23 April). Prior to deployment, the traps were filled with $0.2 \mu \mathrm{m}$ filtered seawater from depths $>100 \mathrm{~m}$ with added salt to increase the salinity by 5 psu (Knap et al. 1996). Hereby, advective diffusive exchange between the higher density, particle-free water and the ambient seawater was reduced in the traps during deployment. No preservative was added.

Immediately after recovery, the sedimentation traps were sealed with a clean lid and protected from direct light. In the laboratory, samples were visually inspected for swimmers, which were removed, and kept at $5^{\circ} \mathrm{C}$ in darkness until analysis $(<2 \mathrm{~h})$. The trap contents were carefully mixed before subsampling. To ensure minimal disturbance of the collected material, samples for microscopic examination were taken first. Subsamples for faecal pellets (600 to $900 \mathrm{ml}$ ) were preserved with $2 \%$ (v/v) acidic Lugol's solution. Analyses for total chl $a_{1}$ phaeo (100 $\mathrm{ml}$ in triplicates), POC and PON (500 ml), and for faecal pellets were performed as described above for the in situ faecal pellet production experiment.

Suspended faecal pellets. Parallel to the trap deployment, water samples were collected using a 301 Niskin bottle at 3 trap deployment depths (20,50, and $100 \mathrm{~m}$ ) for quantification of suspended faecal pellets. The water samples were concentrated on a $20 \mu \mathrm{m}$ sieve, fixed in $2 \%$ (v/v) acidic Lugol's solution, and analysed for faecal pellets and copepod abundance and biomass as described above.

Calculations. The sedimentation rate $\left(\mathrm{mg} \mathrm{m}^{-2} \mathrm{~d}^{-1}\right)$ of the measured variables was calculated from the following equation (Knap et al. 1996):

$$
\text { Sedimentation rate }=\left(C_{\text {trap }} \times V_{\text {trap }}\right) /\left(A_{\text {trap }} \times t_{\text {dep }}\right)
$$

where $C_{\text {trap }}\left(\mathrm{mg} \mathrm{m}^{-3}\right)$ is the concentration of the measured variable in the sediment trap, $V_{\text {trap }}\left(\mathrm{m}^{3}\right)$ is the volume of the sediment trap, $A_{\text {trap }}\left(\mathrm{m}^{2}\right)$ is the sediment trap surface area, and $t_{\text {dep }}(\mathrm{d})$ is the deployment time. Sinking velocity $\left(\mathrm{m} \mathrm{d}^{-1}\right)$ was estimated for different variables using the following equation (Kiørboe et al. 1994):

$$
\text { Sinking velocity }=\text { Sedimentation rate } / C_{\text {in situ }}
$$

where the sedimentation rate is from Eq. (3) and $C_{\text {in situ }}$ $\left(\mathrm{mg} \mathrm{m}^{-3}\right)$ is the in situ concentration of the variables at $50 \mathrm{~m}$ depth.

The daily loss rate $\left(\% \mathrm{~d}^{-1}\right)$ of chl a biomass in the $0-$ $50 \mathrm{~m}$ depth stratum due to sinking export was estimated using the following equation (Olli et al. 2002):

Daily loss rate $=$ Sedimentation rate $\times 100 / C_{\text {int }}$

where sedimentation rate is from Eq. (3) and $C_{\text {int }}$ (mg $\mathrm{m}^{-2}$ ) is the integrated biomass of chl $a$, estimated vertically from integration of the water column measurements at $0-50 \mathrm{~m}$. 
The daily loss $\left(\% \mathrm{~d}^{-1}\right)$ of phytoplankton due to copepod grazing was estimated using Eq. (5) by replacing the sedimentation rate with the copepod grazing calculated from faecal pellet production, i.e. the specific faecal pellet production multiplied by the integrated biomass of copepods $\left(\mathrm{mg} \mathrm{C} \mathrm{m}{ }^{-2}\right.$ ) in the $0-50 \mathrm{~m}$ depth stratum and assuming an assimilation efficiency of 68.2\% (Conover 1966). The present estimate assumes that the copepod prey is dominated by phytoplankton, which is most valid during the bloom. Outside the bloom, protozooplankton can contribute significantly to the diet of Calanus spp. (Levinsen et al. 2000b), and the daily ratio will then be overestimated accordingly.

Statistical procedures. Data was tested for normal distribution using the Shapiro-Wilks test and, if necessary, log transformed. Effects of different mesh sizes in the fecatrons were tested with 1-way ANOVA (Statistica 2004, version 7.0; Statsoft). Linear regressions were determined using ANOVA tests (Sigmaplot 2004, version 10.0, Systat Software) to examine potential relationships between carbon and chl a of the suspended or settled material as well as the relationship between food size and specific ingestion rate. Comparisons of regression lines were done with a 2-tailed $t$-test and accepted as significantly different if $\mathrm{p}<0.05$. The comparison of faecal pellet sizes and sedimentation fluxes could not be fitted to a normal distribution, and a non-parametric analysis followed by a KruskalWallis test was used. Velocity difference of the organic materials was tested with 1-way ANOVA as were differences between the 4 methods for estimate specific ingestion rates. All data are presented as means $\pm \mathrm{SE}$.

\section{RESULTS}

\section{Hydrography and nutrient distribution}

The ice coverage in Disko Bay was $60 \%$ until breakup, between 23 March and 9 April, after which it melted and advected out of the bay. During winter, when sampling took place from the ice station, the water column was stratified with colder $\left(-1.7^{\circ} \mathrm{C}\right)$ surface water separated from a warmer $\left(1.7^{\circ} \mathrm{C}\right)$ bottom

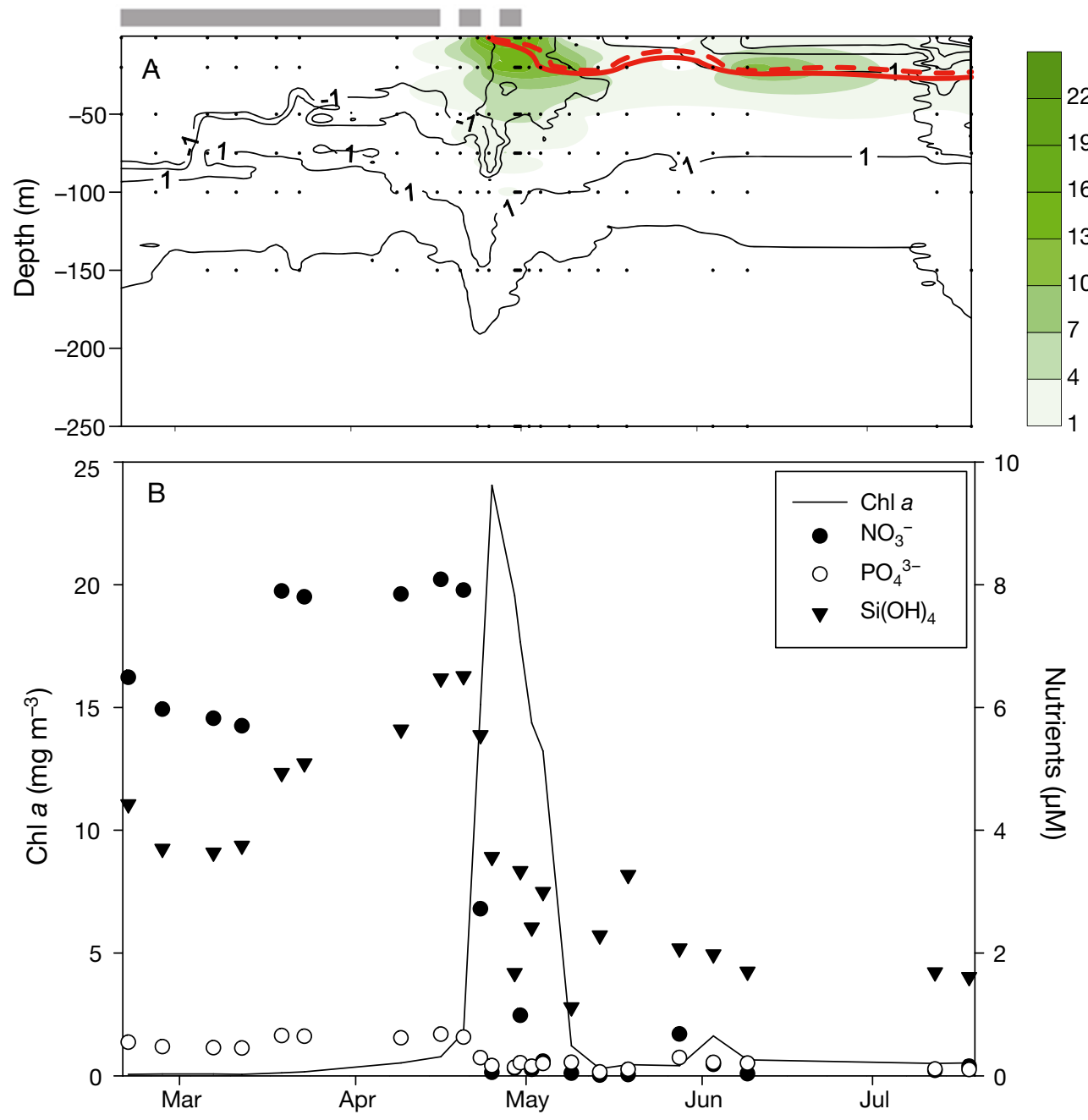

Fig. 2. Water column characteristics over the course of the investigation. (A) Isolines are water temperature $\left({ }^{\circ} \mathrm{C}\right)$ and the green coloration illustrates chlorophyll a (chl a) concentrations $\left(\mathrm{mg} \mathrm{m}^{-3}\right)$. The concentration of the limiting nutrient nitrate is displayed as red isolines (solid: $1.0 \mu \mathrm{M}$, broken: $0.5 \mu \mathrm{M})$. Points: sampling depths. Grey bars indicate ice cover. (B) Succession in the surface layer $(1 \mathrm{~m})$ of chl $a$ and nutrient concentrations 
layer by a thermocline at approximately $60 \mathrm{~m}$ depth (Fig. 2A). During ship-based sampling from 9 April, the weather was dominated by a high pressure system with high irradiance and no wind. The thermocline remained at approximately $60 \mathrm{~m}$ depth as the temperature in the upper layers increased to an average of $-0.9^{\circ} \mathrm{C}$ (Fig. 2A). Towards the end of the investigation, from 9 May, the thermocline approached $20 \mathrm{~m}$, separating the water column into 3 water layers with a warm surface layer, an intermediate layer of cold water $\left(<0.5^{\circ} \mathrm{C}\right)$, and a warm bottom layer (Fig. $2 \mathrm{~A}$ ).

Nitrate was uniformly distributed in the water column at the initiation of the investigation. During the bloom phase the average nitrate concentration in the upper $50 \mathrm{~m}$ stratum decreased from $5.4 \pm 1.5$ to $2.1 \pm$ $1.0 \mu \mathrm{M}$ as a result of the developing bloom (Fig. $2 \mathrm{~A}, \mathrm{~B}$ ). Nitrate concentrations decreased below detection level above $20 \mathrm{~m}$ after 14 May. Phosphorus and silicate distributions mirrored the nitrate development but were not fully depleted. The surface nitrate concentration remained low after the sedimentation of the bloom, and the nutricline followed the stratification for the rest of the study. Comparison of the major nutrients species (Fig. 3) suggests nitrogen limitation of the primary producers, since nitrate became depleted relative to the Redfield ratios with respect to phosphorus (Fig. 3A) and silicate (Fig. 3B) after the ice break-up and initiation of the bloom.

\section{Phytoplankton biomass}

The initiation of the spring bloom (9 April) began at the break-up of sea ice and establishment of the pycnocline. The bloom developed in the upper $20 \mathrm{~m}$ from 23 April and averaged at $11.8 \pm 1.7 \mathrm{mg} \mathrm{chl} \mathrm{a} \mathrm{^{-3 }}(\mathrm{n}=$ 20) during the bloom phase, with a peak of $24.1 \mathrm{mg} \mathrm{m}^{-3}$ on 25 April, followed by a rapid sedimentation out of the photic zone (Fig. 4).

In the present study we divided the phytoplankton bloom into 3 phases. The first phase was defined as the bloom developing phase, (23 to 30 April), followed by the decaying bloom phase ( 2 to 19 May) as the second phase, and the post-bloom phase (28 May to 9 June) as the third phase. The following results are confined to these phases.

Across the 3 depths sampled there was a clear seasonal succession in the size classes of $\mathrm{chl} a$. In the beginning of March, chl $a<10 \mu \mathrm{m}$ dominated the phytoplankton (Fig. 3). During the spring bloom phase, a succession of the 3 size classes was observed initiated by a peak of chl $a<10 \mu \mathrm{m}$, followed by a $10-$ $50 \mu \mathrm{m}$ peak, and culminating with a peak of chl a $>50 \mu \mathrm{m}$. The post-bloom period was dominated by the smallest fraction, i.e. $<10 \mu \mathrm{m}$.

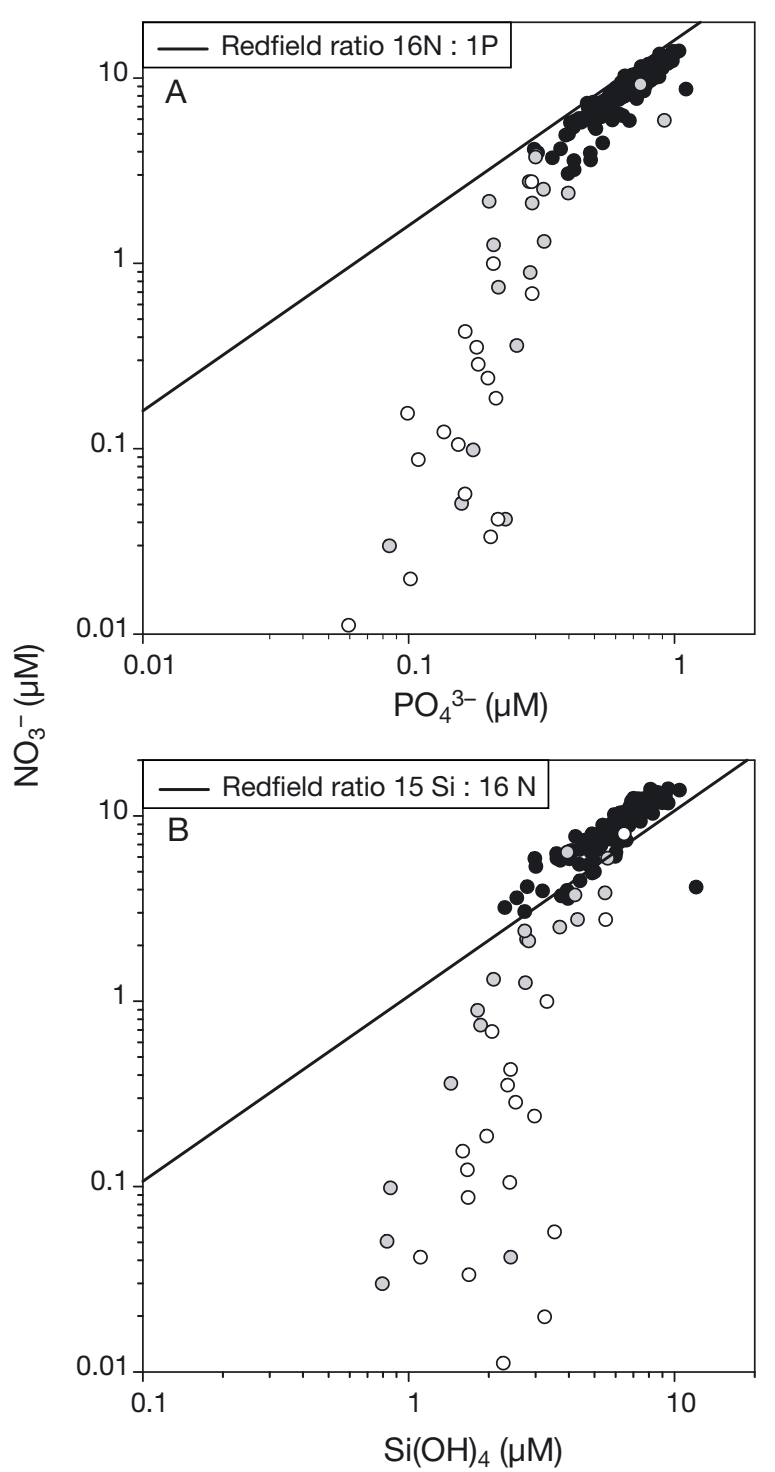

Fig. 3. Relationship between (A) phosphorus and nitrate and (B) silicate and nitrate in the water samples taken from 21 February to 18 July 2008 . (•) samples taken throughout the water column before the initiation of the spring bloom and below the photic zone thereafter $>50 \mathrm{~m}_{\text {; }}(\mathrm{O})$ samples from $20 \mathrm{~m}$ after 20 April and (O) surface samples after 20 April. Lines indicate the Redfield ratios of the nutrients in consideration

The same overall patterns were observed at all depths, with the bloom peaking first in the surface. Total chl $a$ averaged $12.3 \pm 3.4,5.9 \pm 2.7$ and $1.9 \pm 2.2 \mathrm{mg} \mathrm{m}^{-3}$ at 0 to $50 \mathrm{~m}$ depth during the 3 bloom phases, respectively.

The smallest chl a fraction ( 0.7 to $10 \mu \mathrm{m}$ ) contributed on average $31 \%$ to the total $\mathrm{chl} a$ in the upper $50 \mathrm{~m}$ (Fig. 4). At the surface, this fraction had a high average concentration of $5.0 \pm 2.2 \mathrm{mg} \mathrm{m}^{-3}$ in the bloom developing phase, followed by a subsurface bloom $(20 \mathrm{~m})$ with a maximum concentration of $11.9 \pm 0.1 \mathrm{mg} \mathrm{m}^{-3}$ on June 9 .

The medium chl a fraction (10 to $50 \mu \mathrm{m})$ contributed on average $36 \%$ to the total $\mathrm{chl} a$ in the upper $50 \mathrm{~m}$ 
Table 1. Taxonomic composition of the dominating phytoplankton community during the 3 phases of the bloom (S. Soylu unpubl.)

\begin{tabular}{|cccc|}
\hline $\begin{array}{l}\text { Size fraction } \\
(\mu \mathrm{m})\end{array}$ & $\begin{array}{c}\text { Developing bloom } \\
\text { 23-30 April }\end{array}$ & $\begin{array}{c}\text { Decaying bloom } \\
2-19 \text { May }\end{array}$ & $\begin{array}{c}\text { Post bloom } \\
\text { 28 May-9 June }\end{array}$ \\
\hline$<10$ & Phaeocystis pouchetti & P. pouchetii & $\begin{array}{c}\text { Chrysochromulina spp., } \\
\text { Pyramimonas spp., } \\
\text { P. pouchetii }\end{array}$ \\
& & & \\
& & & \\
& Fragilariopsis cylindrus, & F. cylindrus, & \\
F. pseudonana, & F. pseudonana, \\
& Navicula pelagica, & Heterocapsa triquetra, \\
& P. pouchetii & N. pelagica, \\
& & P. pouchetii \\
& F. cylindrus, & F. cylindrus, \\
& F. pseudonana, & F. pseudonana, \\
N. pelagica & N. pelagica \\
\hline
\end{tabular}

copepods. The bulk part of the biomass was mainly located in the upper $50 \mathrm{~m}$, with an average biomass of $3200 \pm$ $800 \mathrm{mg} \mathrm{C} \mathrm{m}$, where Calanus spp. constituted $96 \%$ of the total biomass during all 3 bloom phases. Before the bloom, the biomass consisted primarily of Oithona spp., Pseudocalanus spp., and Microcalanus spp. (Fig. 5). A shift in the biomass composition towards $C$. finmarchicus and C. glacialis was observed later in March. During the spring bloom phase, Calanus spp. dominated with peaks of high biomasses of Metridia longa and Pseudocalanus spp. (Fig. 5A). In this phase, the Calanus

(Fig. 4). The fraction showed a clear unimodal distribution, with high average values both at the surface and subsurface of $7.7 \pm 1.3$ and $6.8 \pm 2.1 \mathrm{mg} \mathrm{m}^{-3}$, respectively, during the bloom developing phase.

The large chl a fraction (>50 $\mu \mathrm{m}$ ) contributed $33 \%$ to the total chl $a$ in the upper $50 \mathrm{~m}$ (Fig. 4), with average concentrations at the surface up to $6.4 \pm 2.5 \mathrm{mg} \mathrm{m}^{-3}$ during the bloom developing phase. Subsurface concentrations showed a clear bimodal distribution during the developing and decaying bloom phase, with a maximum of $14.2 \pm 0.04 \mathrm{mg} \mathrm{m}^{-3}$ on 9 May, and an average of $5.0 \pm 2.5 \mathrm{mg} \mathrm{m}^{-3}$.

All chl a fractions at $50 \mathrm{~m}$ depth had maximum values approximately 3 to $4 \times$ lower than the concentrations in the depths above (Fig. 4).

The succession illustrated by the size fractionated chl a measurements (Fig. 4) was corroborated by microscopic examinations of the Lugol's fixed samples (Table 1). The winter plankton was dominated by haptophytes (primarily Phaeocystis pouchetii). Single cells of $P$. pouchetii also dominated the initial phase (chl $a<10 \mu \mathrm{m}$ ) of the spring bloom (Fig. 4), followed by a gradual shift to the diatom species of Fragilariopsis cylindrus and Navicula pelagica after the bloom, first as single cells and later as chain formations during the exponential growth of the bloom. After the bloom peaked and became nutrient-depleted, chains of $F$. cylindrus and $N$. pelagica $(>50 \mu \mathrm{m})$ sedimented out of the euphotic zone. The summer plankton was dominated by small flagellates $<10 \mu \mathrm{m}$ (Table 1 ). The same succession patterns were observed in all 3 strata investigated. Further details on the phytoplankton succession and sedimentation are presented in S. Soylu et al. (unpubl.).

\section{Copepod biomass}

In all 5 depth strata sampled, a clear seasonal succession was observed in the species composition of the species was mainly represented as adult females ( $R$. Swalethorp et al. unpubl.). During the decaying bloom phase, the biomass consisted mainly of C. hyperboreus, which peaked in early May. During the postbloom phase the biomass of copepods decreased with C. hyperboreus as the dominating Calanus spp. and Pseudocalanus spp. contributing to the main biomass of the smaller copepods. The biomass decreased with depth, although large biomasses were located in the 50-100 m depth stratum, averaging $2200 \pm 600 \mathrm{mg} \mathrm{C}$ $\mathrm{m}^{-2}$, and dominated by Calanus (93\% of the total biomass) during all 3 bloom phases (Fig. 5B). However, $M$. longa increased in biomass with depth (Fig. 5C,D). A high biomass of $C$. hyperboreus was observed during the spring bloom phase at the deepest sampling depth (Fig. 5E), followed by a low biomass during the decaying bloom phase, which suggests a vertical ascent of C. hyperboreus towards the surface during this phase. An increase in the biomass of C. hyperboreus was observed during the post-bloom phase at the 2 deepest depth strata (Fig. 5D,E). Here C. hyperboreus contributed with 63 and $89 \%$ to the biomass, respectively, suggesting a vertical migration of C. hyperboreus towards the overwintering depths at the bottom.

\section{Gut fluorescence}

Overall, the specific ingestion rate ranged between 0.01 and $74 \% \mathrm{~d}^{-1}$ for the Calanus spp., with an overall average of $10.3 \pm 2.2 \% \mathrm{~d}^{-1}(\mathrm{n}=38)$ (Fig. 6, Table 2). The specific ingestion rate for $C$. finmarchicus at the initiation of the bloom reached $74 \% \mathrm{~d}^{-1}$ on 30 April (Fig. 6B). The average specific ingestion rate for C. finmarchicus was $17.5 \pm 5.7 \% \mathrm{~d}^{-1}(\mathrm{n}=13)$ during all 3 bloom phases and decreased significantly in the postbloom phase $(\mathrm{p}<0.01, \mathrm{n}=13)$.

The specific ingestion rate for Calanus glacialis followed the pattern of $C$. finmarchicus, reaching $20 \%$ 
$\mathrm{d}^{-1}$ on 9 May. It decreased significantly in the postbloom phase $(\mathrm{p}<0.01, \mathrm{n}=13)$, and the average specific ingestion rate for $C$. glacialis was $7.0 \pm 1.9 \% \mathrm{~d}^{-1}(\mathrm{n}=$ 13) during all 3 bloom phases (Fig. 6C). The specific ingestion rate for $C$. hyperboreus reached $15 \% \mathrm{~d}^{-1}$ on 4 May, with an average of $2.1 \pm 0.5 \% \mathrm{~d}^{-1}(\mathrm{n}=12)$ during all 3 bloom phases (Fig. 6D) and a significant decrease in the post-bloom phase $(\mathrm{p}<0.01, \mathrm{n}=12)$.

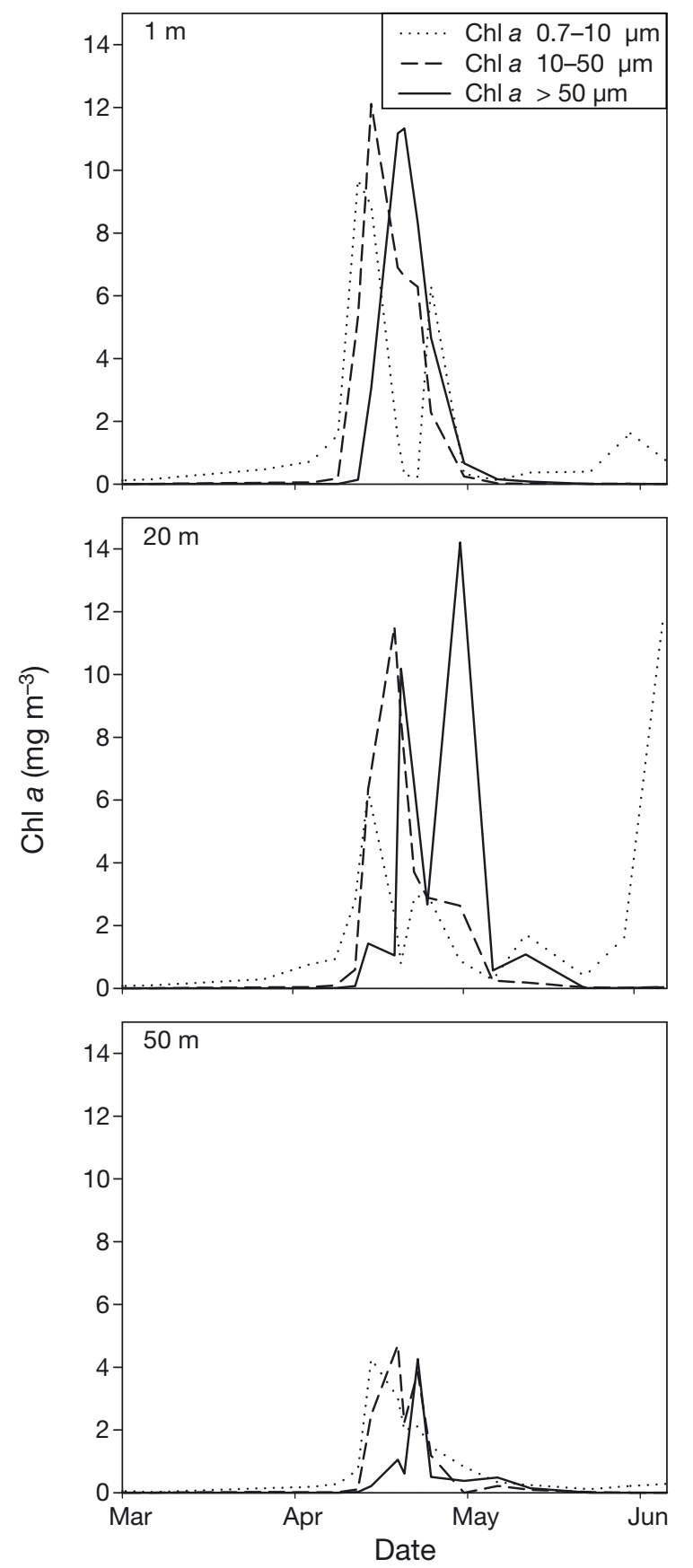

Fig. 4. Size fractionated chl a concentrations $(0.7-10 \mu \mathrm{m}$, $10-50 \mu \mathrm{m}$, and $>50 \mu \mathrm{m})$ at 1,20 , and $50 \mathrm{~m}$ depths

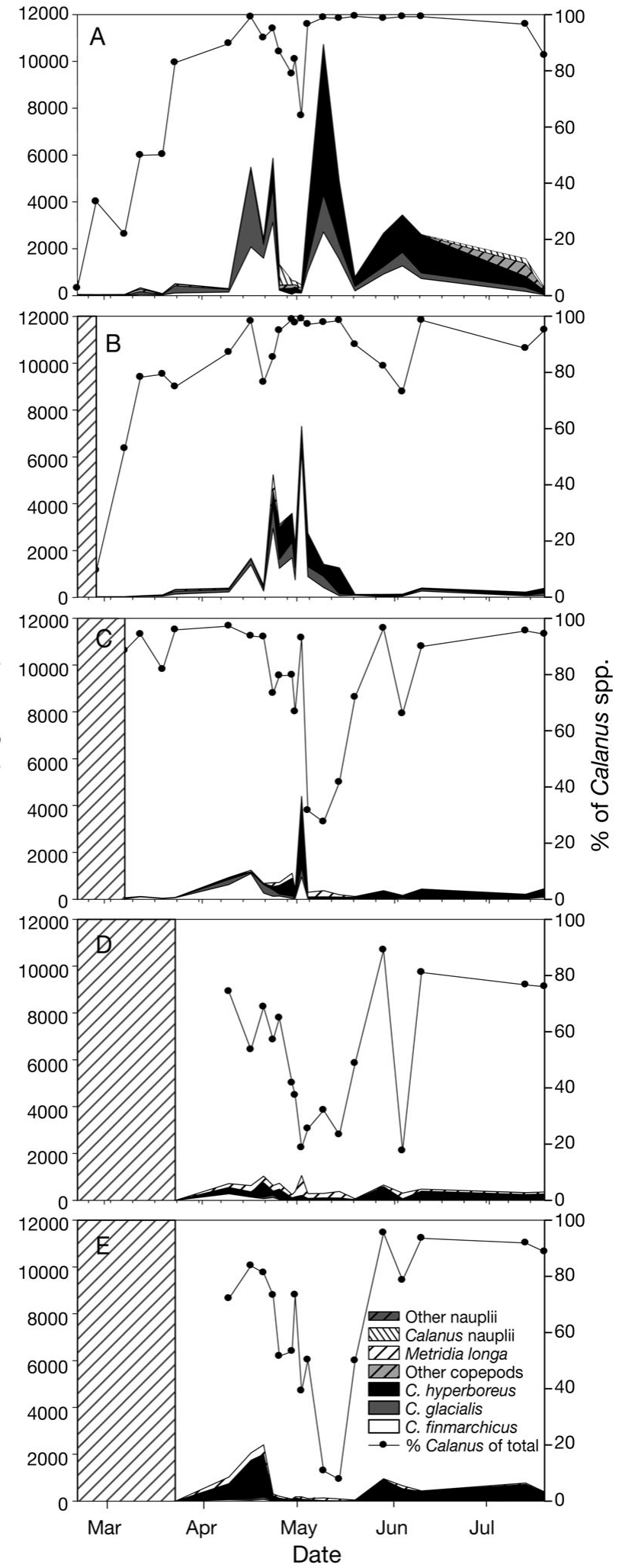

Fig. 5. Integrated biomasses of copepods $\left(\mathrm{mg} \mathrm{C} \mathrm{m}^{-2}\right)$ in (A) 0-50 m depth, (B) 50-100 m depth, (C) 100-150 m depth, (D) 150-200 m depth, and (E) 200-250 m depth stratum. Solid line: contribution of Calanus spp. (\%) to total copepod biomass. Vertical black line: initiation of sampling at depths 

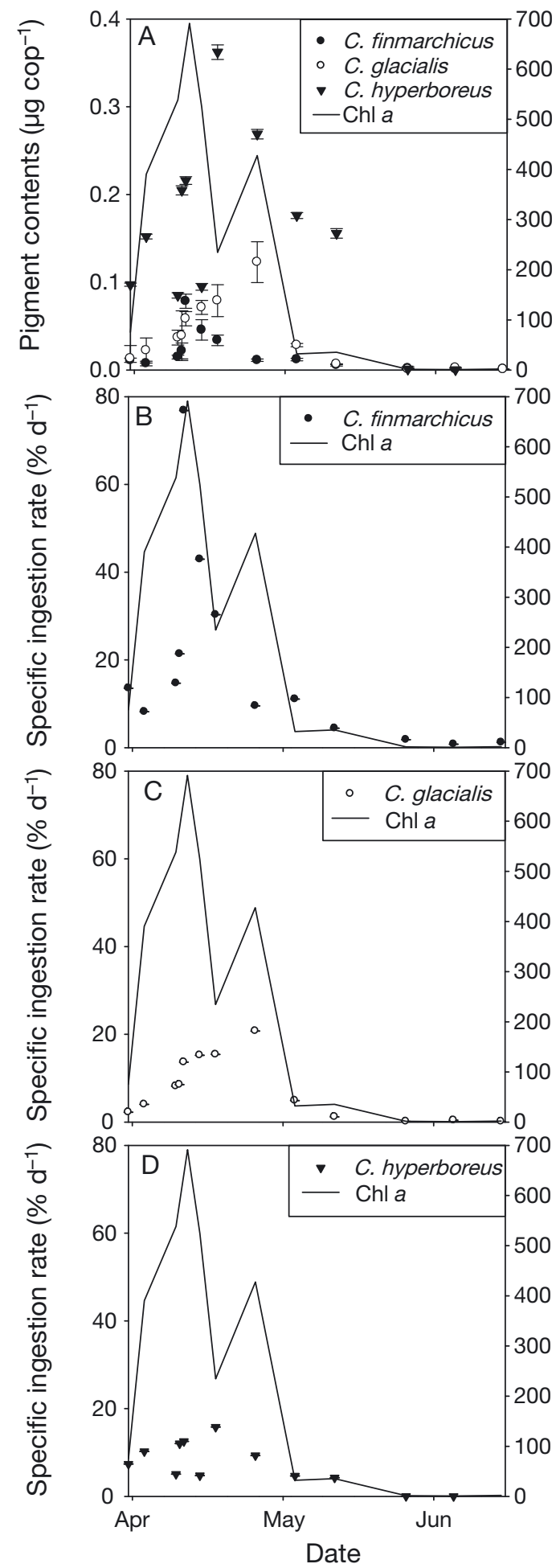

Fig. 6. (A) Gut pigment content ( $\mu \mathrm{g})$ of Calanus spp. from gut fluorescence measurements. $(B, C, D)$ Specific ingestion rates $\left(\% \mathrm{~d}^{-1}\right)$ calculated from gut fluorescence measurements for (B) C. finmarchicus, (C) C. glacialis, and (D) C. hyperboreus. Data are averages \pm SE. Solid line: integrated chl $a>10 \mu \mathrm{m}$ $\left(\mathrm{mg} \mathrm{m}^{-2}\right)$ for the $0-50 \mathrm{~m}$ depth stratum
A correlation analysis of the specific ingestion rates of Calanus spp. and the integrated chl a size fractions from 0 to $50 \mathrm{~m}$ showed that 74,72 , and $57 \%$ of the variation in specific ingestion rates could be explained by the integrated concentration of the chl a >10 $\mu \mathrm{m}$ for C. finmarchicus, C. glacialis, and C. hyperboreus, respectively, although not significantly for $C$. hyperboreus $(\mathrm{p}>0.05, \mathrm{n}=12)$. Furthermore, correlation analyses for chl $a>50 \mu \mathrm{m}$ revealed a significant correlation of $89 \%$ of specific ingestion rate by $C$. glacialis, while the correlations of $C$. finmarchicus and C. hyperboreus remained unchanged compared to the chl $a>10 \mu \mathrm{m}$. Consequently, the ingestion calculated from the gut pigment of Calanus spp. was compared with chl a $>10 \mu \mathrm{m}$ representing the potential food for Calanus (Fig. 6).

All the Calanus spp. responded positively to the developing bloom (Fig. 6). A clear response was observed in the gut pigment content of $C$. hyperboreus at the initiation of the bloom, while the responses were more modest for C. finmarchicus and C. glacialis (Fig. 6A). Likewise, the gut pigment content of all Calanus spp. decreased with the termination of the chl a bloom.

All background values measured were low; $0.001 \pm$ $0.02(\mathrm{n}=45), 0.002 \pm 0.02(\mathrm{n}=25)$, and $0.01 \pm 0.001 \mu \mathrm{g}$ female $^{-1}(\mathrm{n}=20)$ for $C$. finmarchicus, C. glacialis, and C. hyperboreus, respectively.

\section{In situ faecal pellet production experiment}

There was no difference between the in situ faecal pellet production measured using the 2 types of fecatrons with different mesh sizes ( $p>0.05, n=89)$. Consequently, the results represent an average of the 2 fractions $(n=8)$. No correlation was found between specific ingestion rate by copepod spp. and chl a size fractions from the surface water $(1 \mathrm{~m})(\mathrm{p}>0.05, \mathrm{n}=11)$. It was assumed that the food size spectra for the copepod spp. were the same as observed for the specific ingestion rate during the gut pigment measurements and observed in the incubations of individual Calanus for faecal pellet production measurements from $\mathrm{R}$. Swalethorp et al. (unpubl.). Consequently, production measurements by the in situ faecal pellet productions experiment of Calanus spp. are presented along with chl $a>10 \mu \mathrm{m}$ representing the potential food for the copepods (Fig. 7).

Faecal pellet production rate (FPR) followed the bloom, with a peak after the culmination of the bloom and a decrease to a stable FPR during the post-bloom phase (Fig. 7A). Overall average FPR was $20 \pm 2.2$ pellets ind..$^{-1} \mathrm{~d}^{-1}(\mathrm{n}=89)$, with a maximum during the decaying bloom of $27 \pm 2.9$ pellets animal ${ }^{-1} \mathrm{~d}^{-1}(\mathrm{n}=37)$. Faecal pellet volumes increased significantly $(p<0.01$, 
Table 2. Integrated phytoplankton and copepod biomass in the upper $50 \mathrm{~m}$ and specific ingestion rates and corresponding grazing impact (\% of phytoplankton biomass $\mathrm{d}^{-1}$; $\mathrm{PB}$ ) estimated by 4 methods: (A) in situ faecal pellet production experiment, (B) average gut fluorescence in 3 Calanus spp., (C) average faecal pellet (FP) production from bottle incubations of 3 Calanus spp., and (D) egg production by C. finmarchicus and C. glacialis. Data are averages \pm SE. No. of samples given in parentheses

\begin{tabular}{|c|c|c|c|c|c|c|c|c|c|c|c|c|}
\hline \multirow[t]{2}{*}{ Phase } & \multicolumn{2}{|c|}{ Biomass $\left(\mathrm{g} \mathrm{C} \mathrm{m}^{-2}\right)$} & \multirow[b]{2}{*}{$\begin{array}{l}\text { (A) In situ } \\
\text { FP pro- } \\
\text { duction } \\
\left(\% d^{-1}\right)\end{array}$} & \multicolumn{7}{|c|}{ Specific ingestion rate and grazing impact } & \multirow[b]{2}{*}{$\begin{array}{c}(\mathrm{A}, \mathrm{B}, \mathrm{C}, \mathrm{D}) \\
\text { Average } \\
\text { produc- } \\
\text { tion } \\
\left(\% \mathrm{~d}^{-1}\right)\end{array}$} & \multirow{2}{*}{$\begin{array}{l}\% \\
\text { of } \\
\text { PB }\end{array}$} \\
\hline & $\begin{array}{l}\text { Phyto- } \\
\text { plankton }\end{array}$ & $\begin{array}{l}\text { Cope- } \\
\text { pod }\end{array}$ & & $\begin{array}{c}\% \\
\text { of } \\
\text { PB }\end{array}$ & $\begin{array}{c}\text { (B) Gut } \\
\text { fluores- } \\
\text { cence } \\
\left(\% d^{-1}\right)\end{array}$ & $\begin{array}{c}\% \\
\text { of } \\
\text { PB }\end{array}$ & $\begin{array}{c}(\mathrm{C}) \\
\text { FP pro- } \\
\text { duction } \\
\left(\% \mathrm{~d}^{-1}\right)\end{array}$ & $\begin{array}{l}\% \\
\text { of } \\
\text { PB }\end{array}$ & $\begin{array}{c}\text { (D) Egg } \\
\text { pro- } \\
\text { duction } \\
\left(\% d^{-1}\right)\end{array}$ & $\begin{array}{c}\% \\
\text { of } \\
\text { PB }\end{array}$ & & \\
\hline \multicolumn{13}{|c|}{ Developing bloom } \\
\hline 23-30 April & $\begin{array}{c}18.3 \pm 2.7 \\
(5)\end{array}$ & $\begin{array}{c}2.7 \pm 1.1 \\
(5)\end{array}$ & $\begin{array}{c}2.9 \pm 0.6 \\
(29)\end{array}$ & 0.4 & $\begin{array}{l}14.1 \pm 4.4 \\
\quad(15)\end{array}$ & 2.1 & $\begin{array}{c}2.2 \pm 0.3 \\
(164)\end{array}$ & 0.3 & $\begin{array}{c}5.6 \pm 0.4 \\
(93)\end{array}$ & 0.8 & 6.4 & 1.0 \\
\hline \multicolumn{13}{|c|}{ Decaying bloom } \\
\hline 2-19 May & $\begin{array}{c}9.4 \pm 3.3 \\
\quad(5)\end{array}$ & $\begin{array}{c}4.0 \pm 1.9 \\
(5)\end{array}$ & $\begin{array}{c}6.0 \pm 1.3 \\
(37)\end{array}$ & 2.5 & $\begin{array}{c}12.5 \pm 2.8 \\
(15)\end{array}$ & 5.3 & $\begin{array}{c}2.1 \pm 0.3 \\
(197)\end{array}$ & 0.9 & $\begin{array}{c}7.4 \pm 0.5 \\
(133)\end{array}$ & 3.2 & 7.2 & 3.4 \\
\hline \multicolumn{13}{|l|}{ Post bloom } \\
\hline $\begin{array}{l}28 \text { May- } \\
9 \text { June }\end{array}$ & $\begin{array}{c}3.8 \pm 2.7 \\
(3)\end{array}$ & $\begin{array}{c}2.9 \pm 0.3 \\
(5)\end{array}$ & $\begin{array}{c}3.1 \pm 0.9 \\
(23)\end{array}$ & 2.3 & $\begin{array}{c}0.7 \pm 0.3 \\
(9)\end{array}$ & 0.5 & $\begin{array}{c}0.5 \pm 0.1 \\
(164)\end{array}$ & 0.4 & $\begin{array}{c}1.8 \pm 0.3 \\
(47)\end{array}$ & 1.4 & 1.6 & 1.6 \\
\hline
\end{tabular}

$\mathrm{n}=5563$ ) throughout the 3 phases, with averages of 1.1 $\pm 0.02 \times 10^{6} \mu \mathrm{m}^{3}(\mathrm{n}=1920), 1.5 \pm 0.02 \times 10^{6} \mu \mathrm{m}^{3}(\mathrm{n}=$ 2283), and $1.6 \pm 0.04 \times 10^{6} \mu^{3}(\mathrm{n}=1360)$, respectively (Fig. 8A).

Specific ingestion rates showed a delayed response to increased chl a. Specific ingestion rates peaked during the decaying bloom phase at $15.6 \pm 3.8 \% \mathrm{~d}^{-1}$ $(n=8)$, then decreased to $4.3 \pm 0.6 \% d^{-1}(n=8)$ and remained constant until the last sampling date (Fig. 7C). The overall average was $6.7 \pm 0.7 \% d^{-1}(n=89)$ (Fig. 7C, Table 1).

From the 2 independent methods, in situ faecal pellet production experiment and gut fluorescence, copepod specific ingestion rates were evaluated and compared. Furthermore, 2 other measures from a concurrent study were included in the comparison (R. Swalethorp et al. unpubl.). Egg and faecal pellet production were measured for adult females of the 3 Calanus species individually in bottle incubations. Here, the average of the 3 Calanus spp. is presented for faecal pellet production, and the average of $C$. finmarchicus and C. glacialis for egg production, since $C$. hyperboreus were not producing any eggs during the time of the study.

Estimated specific ingestion rates from the bottle incubations were calculated from the specific egg and faecal pellet productions assuming a growth and assimilation efficiency of 33 and $68.2 \%$, respectively (Conover 1966, Hansen et al. 1997) and that specific ingestion rates by Calanus could be considered representative for the entire copepod community. Grazing impacts on the phytoplankton community assessed using the 4 methods are estimated by multiplying specific ingestion rate by copepod biomass (Table 2). Differences between the estimated ingestion rates of the 4 methods are evaluated in the 'Discussion'.

\section{Sedimentation}

POC sedimentation averaged $1.4 \pm 0.1 \mathrm{~g} \mathrm{C} \mathrm{m}^{-2} \mathrm{~d}^{-1}$ ( $n=68$ ) from the $0-100 \mathrm{~m}$ depth during all 3 phases (Fig. 9). Sedimentation rates at $20 \mathrm{~m}$ were approximately $2 \times$ higher than at 50 and $100 \mathrm{~m}$. The bulk part of PPC sedimentation was observed in the upper $20 \mathrm{~m}$, with an increasing trend during the developing bloom, ranging from 0.3 to $3.0 \mathrm{~g} \mathrm{C} \mathrm{m}^{-2} \mathrm{~d}^{-1}$ (Fig. 9). This was reflected by high phytoplankton biomass in the euphotic layer and relatively low grazing rates, suggesting passively sinking PPC from the productive layer. PPC sedimentation rates increased in relation to the subsurface bloom at the end of the post-bloom phase (Fig. 9). PPC contributed with an average of $1.1 \pm 0.4 \mathrm{~g} \mathrm{C} \mathrm{m}^{-2} \mathrm{~d}^{-1}(\mathrm{n}=$ 5), equivalent to $60 \%$ of POC sedimentation in the upper $50 \mathrm{~m}$ during the developing bloom. A relatively lower sedimentation of PPC was observed at $100 \mathrm{~m}$ with $0.4 \pm 0.2 \mathrm{~g} \mathrm{C} \mathrm{m}^{-2} \mathrm{~d}^{-1}$, yet this was equivalent to $57 \%$ of POC at $100 \mathrm{~m}$ in the developing bloom phase. PPC sedimentation decreased towards the post-bloom phase, with contributions of 18 to $25 \%$ of POC in the upper $50 \mathrm{~m}$ and 11 to $35 \%$ at $100 \mathrm{~m}$ in the post-bloom phase. The overall average of PPC was $0.5 \pm 0.06 \mathrm{~g} \mathrm{C}$ $\mathrm{m}^{-2} \mathrm{~d}^{-1}(\mathrm{n}=78)$ at 0 to $100 \mathrm{~m}$ depth contributing $36 \%$ to the total POC sedimentation.

Seasonal development in sedimentation of amorphous detritus followed the PPC (Fig. 9). Sedimentation of amorphous detritus was of high importance during the post-bloom phase, contributing 71 to $79 \%$ to POC sedimentation in the upper $50 \mathrm{~m}$ and 10 to $70 \%$ at $100 \mathrm{~m}$. On average, the relative importance of sedimenting amorphous detritus exceeded that of PPC both in the decaying and post-bloom phases. The overall average of amorphous detritus was $0.7 \pm 0.1 \mathrm{~g} \mathrm{C} \mathrm{m}^{-2} \mathrm{~d}^{-1}$ ( $\mathrm{n}=68)$, contributing $52 \%$ to total POC sedimentation. 


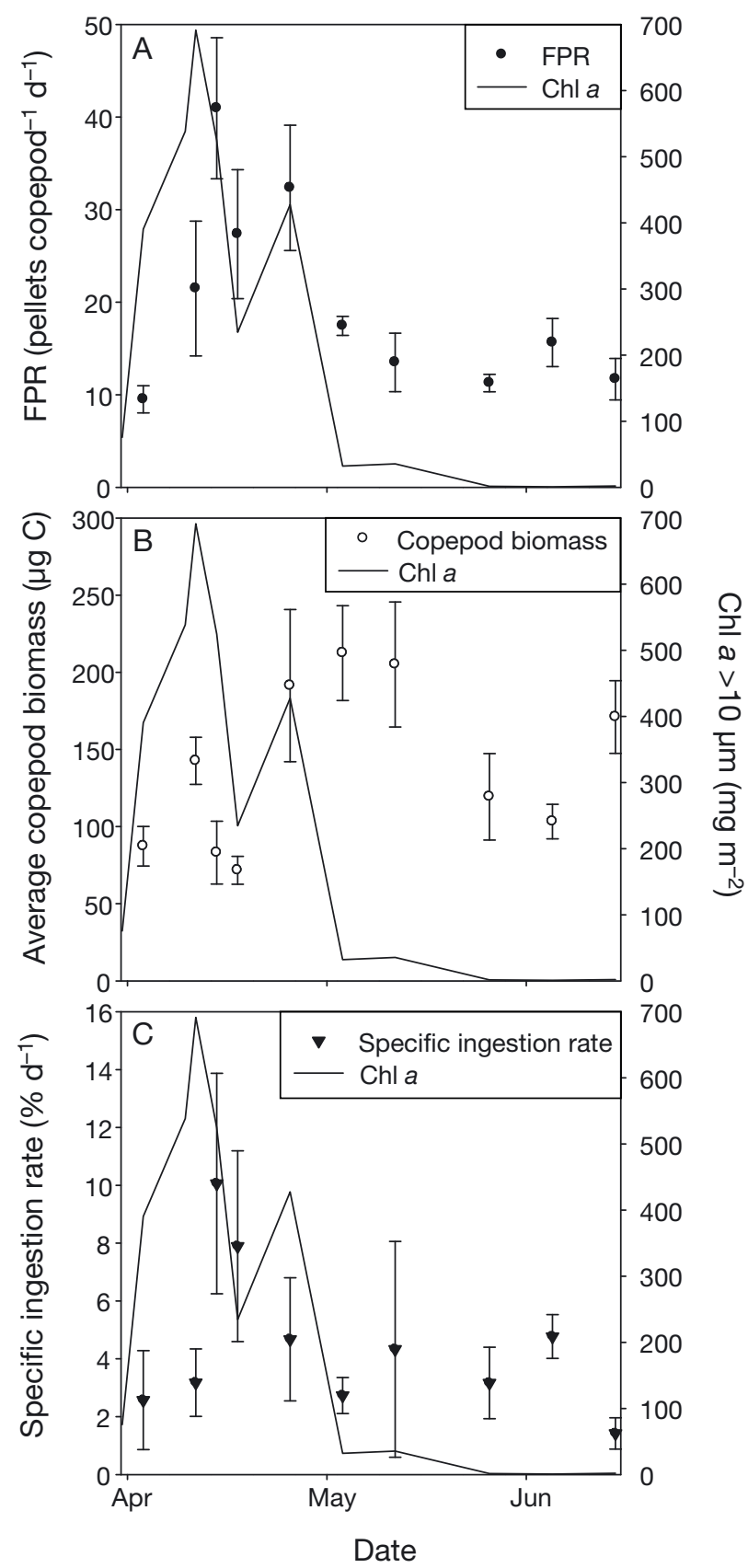

Fig. 7. (A) Faecal pellet production rate (FPR; number of pellets copepod $\mathrm{d}^{-1} \mathrm{~d}^{-1}$ of the in situ copepod community. (B) Individual copepod biomass ( $\mu \mathrm{g} \mathrm{C}$ copepod $^{-1}$ ), (C) specific ingestion rates $\left(\% \mathrm{~d}^{-1}\right)$. Data are averages \pm SE. Solid line: integrated chl a $>10 \mu \mathrm{m}\left(\mathrm{mg} \mathrm{m}^{-2}\right)$ for the $0-50 \mathrm{~m}$ depth stratum

The highest FPC sedimentation was measured at $100 \mathrm{~m}$ depth in the decaying bloom phase, ranging from 0.3 to $0.4 \mathrm{~g} \mathrm{C} \mathrm{m}^{-2}$ (Fig. 9) corresponding to 10 to $43 \%$ of POC. Sedimentation of FPC at $100 \mathrm{~m}$ was significantly different between the decaying and post-bloom phases $(\mathrm{p}<0.05, \mathrm{n}=26)$. These findings correspond well with larger faecal pellets found in the sediment

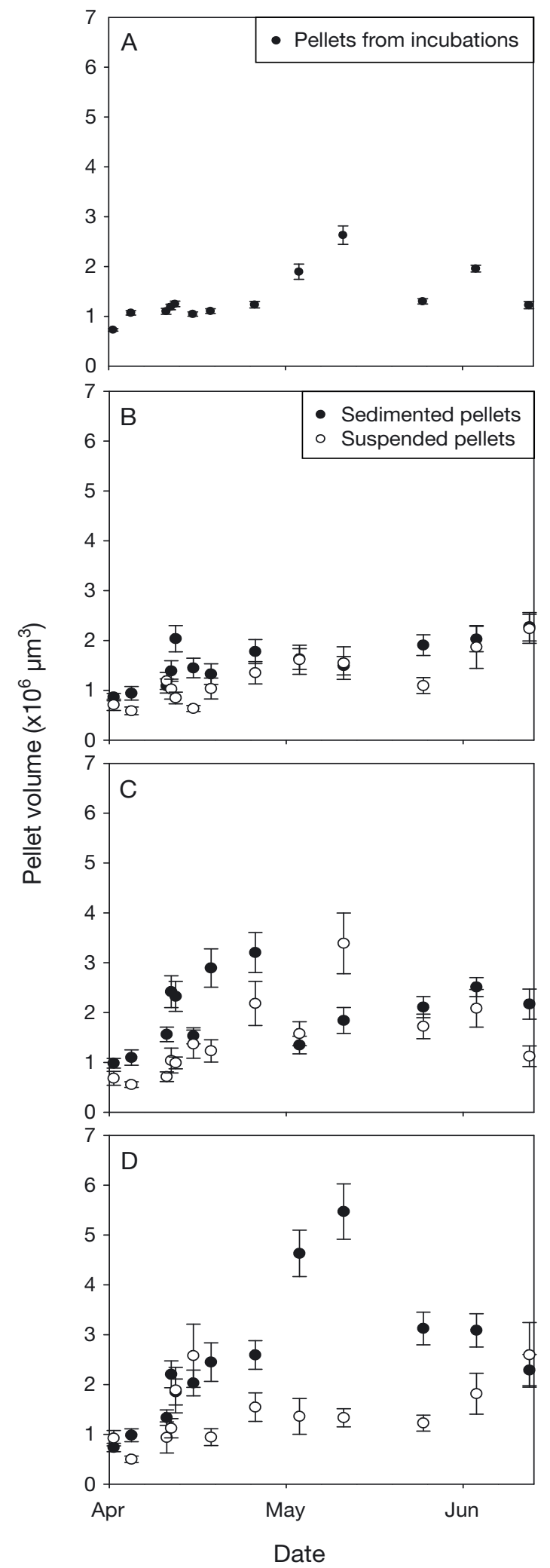

Fig. 8. (A) Volume of faecal pellets from in situ faecal pellet production experiments. (B,C,D) Volume of faecal pellets from sediment traps and water column at (B) $20 \mathrm{~m}$, (C) $50 \mathrm{~m}$, and (D) $100 \mathrm{~m}$ depths. Data are averages $\pm \mathrm{SE}$ 


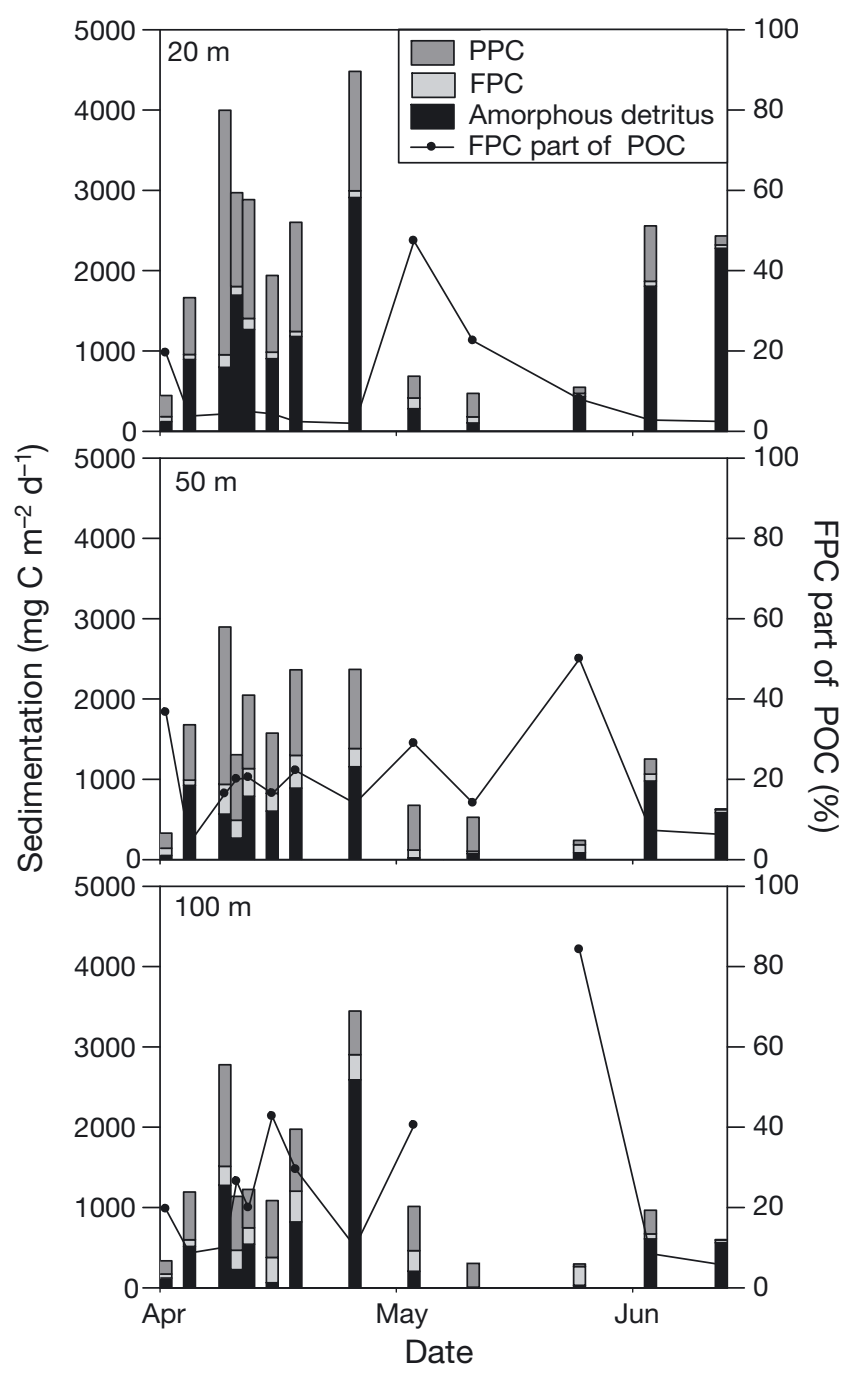

Fig. 9. Seasonal trends in sedimentation of phytoplankton based carbon (PPC), faecal pellet based carbon (FPC), and amorphous detritus fractions of POC $\left(\mathrm{mg} \mathrm{C} \mathrm{m}^{-2} \mathrm{~d}^{-1}\right)$ at 20, 50, and $100 \mathrm{~m}$ depths. Solid lines: FPC part of POC sedimen-

tation. The FPC sample is missing on May 19 at $100 \mathrm{~m}$

traps at $100 \mathrm{~m}$ during the decaying phase (Fig. 8D). Faecal pellets found in the sediment traps also differed significantly in size from the suspended faecal pellets at 20, 50, and $100 \mathrm{~m}$ depths during the developing and post-bloom phases $(\mathrm{p}<0.01, \mathrm{n}=1349)$ and $(\mathrm{p}<0.01, \mathrm{n}=$ 806), respectively (Fig. 7B,C,D). The overall average of FPC sedimentation was $0.16 \pm 0.1 \mathrm{~g} \mathrm{C} \mathrm{m}^{-2} \mathrm{~d}^{-1}(\mathrm{n}=78)$, contributing $12 \%$ to total POC sedimentation.

\section{Biochemical composition of the suspended and settled biomass}

In general, the bulk of suspended POC and PON was collected in the upper $20 \mathrm{~m}$, where POC peaked at 887 $\mathrm{mg} \mathrm{C} \mathrm{m} \mathrm{m}^{-3}$ on 29 April. The POC/PON ratio indicates the quality of organic material, as degradation increases the ratio from the Redfield ratio of 6.6. The general trend was that the elementary composition of POC/PON ratios increased with depth and throughout the season (Table 3).

The average suspended POC/PON ratio was $\sim 7$ in the upper $50 \mathrm{~m}$ during the developing and decaying phases, with an increase in the post-bloom phase. The increase suggests a nitrate limitation, but no significant correlation was observed between the POC/PON ratio and nitrate concentrations ( $p>0.05, n=9)$. None of the suspended POC/PON ratios were significantly different between depths during all 3 phases ( $p>0.05$, $n=40$ ) (Table 3 ). The POC/PON ratio of the settled material during the developing bloom phase at $100 \mathrm{~m}$ depth was 6.9 (Table 3). The ratio increased during the decaying bloom phase and ended at 16 in the postbloom phase at $100 \mathrm{~m}$. This suggests that the settling phytoplankton may have been nutrient-limited during the last phase. However, no significant correlation was observed between POC/PON ratio and nitrate concentration ( $\mathrm{p}>0.05, \mathrm{n}=9$ ).

The relation between suspended POC and chl a was fitted to a linear regression:

$$
\begin{aligned}
& \mathrm{POC}=29.9 \pm 1.3 \times \mathrm{chl} a+113.9 \pm 10.3 \\
& \left(\mathrm{r}^{2}=0.87, \mathrm{n}=88, \mathrm{p}<0.01\right)
\end{aligned}
$$

The slope of the regression line was used to convert suspended and sedimentated chl a measurements into PPC.

The suspended POC/chl a ratio increased from $\sim 50$, measured during the developing bloom phase, to 300 during the post-bloom phase. The ratio did not change significantly with depth during all 3 phases $(p>0.05$, $\mathrm{n}=56$ ).

For the settled material, the linear regression between the POC and chl a measurements was:

$$
\begin{aligned}
& \mathrm{POC}=40.8 \pm 4.2 \times \mathrm{chl} a+191.8 \pm 55.2 \\
& \left(\mathrm{r}^{2}=0.6, \mathrm{n}=68, \mathrm{p}<0.01\right)
\end{aligned}
$$

The POC/chl a ratio of 300 measured for the settled material in the post-bloom phase was significantly higher than for the developing and decaying bloom phases $(\mathrm{p}<0.01, \mathrm{n}=36)$, which suggests that the settling material consisted mainly of degraded material (data not shown).

The chl a/phaeo ratio can be taken as a proxy for grazing, since increased degradation of chl a to phaeo pigment led to a decrease of the chl a/phaeo ratio. The suspended chl a/phaeo ratio decreased from 30 in the bloom developing phase to 5 in the post-bloom phase (data not shown). The ratio in the settled material was 2 in the bloom developing phase at $100 \mathrm{~m}$, after which it decreased to $<1$ during the decaying bloom and the post-bloom phases. 


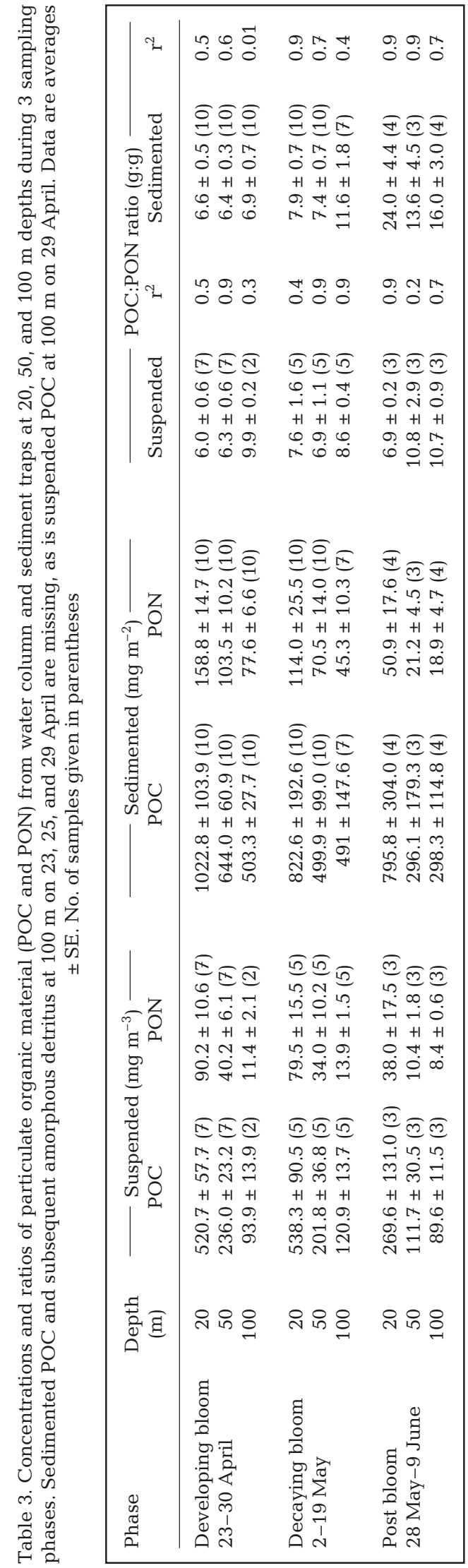

\section{Loss rates}

Sinking velocity of particulate material increased with increasing depth (except amorphous detritus) (Table 4). Sinking velocity of FPC was approximately one order of magnitude higher than PPC and amorphous detritus (Table 4).

Estimated daily loss rates of PPC due to sedimentation were generally high in the first 2 phases (Fig. 10), with an average daily loss rate of $5.1 \pm 1.6 \% \mathrm{~d}^{-1}(\mathrm{n}=$ 13) equivalent to a loss of $0.6 \pm 0.01 \mathrm{~g} \mathrm{C} \mathrm{m}^{-2} \mathrm{~d}^{-1}$ during all 3 bloom phases. The average daily loss rate of PPC due to copepod grazing was $4.1 \pm 1.5 \% \mathrm{~d}^{-1}(\mathrm{n}=13)$. This was equivalent to an average loss of $0.2 \pm 0.06 \mathrm{~g} \mathrm{C}$ $\mathrm{m}^{-2} \mathrm{~d}^{-1}$ during all 3 bloom phases.

\section{Copepod community grazing impact}

The specific ingestion rates calculated from the applied methods were variable; however they showed similar trends, with higher rates during the bloom relative to the post-bloom period (Table 2). In general, the lowest estimates originate from bottle incubations (i.e. the egg and faecal pellet production), while the in situ measurements (i.e. gut fluorescence and in situ faecal pellet production method) resulted in higher rates. Variation in the specific ingestion rate estimates of the different methods varied with bloom phase. The gut fluorescence method values was significantly higher than those originating from the faecal pellet production method, with bottle incubations during the first 2 bloom phases $(p<0.01, n=21)$ and $(p<0.01, n=25)$, respectively. Ingestion measured from in situ faecal pellet production was significantly higher than that from the faecal pellet production from bottle incuba-

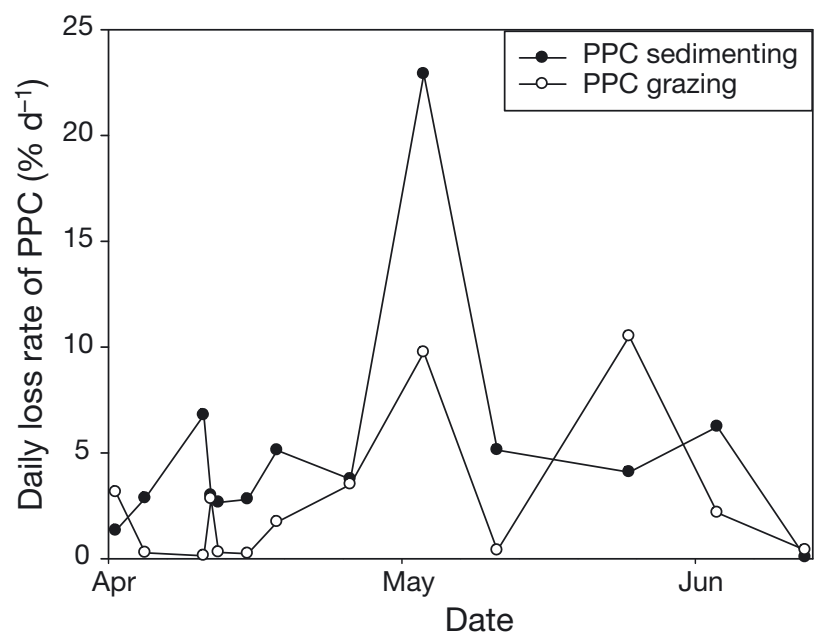

Fig. 10. Daily loss rates $\left(\% \mathrm{~d}^{-1}\right)$ of phytoplankton based carbon (PPC), caused by grazing by copepods (Table 1) and sedimentation at the 0 to $50 \mathrm{~m}$ depth stratum 
Table 4. Sinking velocities of total particulate organic carbon (POC) and its fractions (PPC, FPC, and amorphous detritus) at 20, 50, and $100 \mathrm{~m}$ depths during 3 sampling phases. POC and, subsequently, amorphous detritus at $100 \mathrm{~m}$ on 23, 25, and 29 April are missing. Data are averages \pm SE. No. of samples given in parentheses

\begin{tabular}{|lccccc|}
\hline \multirow{2}{*}{ Phase } & \multirow{2}{*}{ Depth $(\mathrm{m})$} & \multicolumn{3}{c|}{ Velocity $\left(\mathrm{m} \mathrm{d}^{-1}\right)$} & \multirow{2}{*}{ Amorphous detritus } \\
\cline { 3 - 5 } & & POC & PPC & \\
\hline Developing bloom & 20 & $4.1 \pm 0.6(10)$ & $2.7 \pm 0.6(10)$ & $117.4 \pm 35.0(10)$ & $25.5 \pm 14.7(10)$ \\
23-30 April & 50 & $6.0 \pm 1.0(10)$ & $5.3 \pm 1.6(10)$ & $174.1 \pm 59.7(10)$ & $19.6 \pm 18.3(10)$ \\
& 100 & $10.5 \pm 1.0(4)$ & $18.9 \pm 2.7(10)$ & $108.0 \pm 13.7(10)$ & $6.0 \pm 2.1(4)$ \\
Decaying bloom & 20 & $3.3 \pm 0.7(10)$ & $3.2 \pm 0.5(10)$ & $35.5 \pm 5.1(10)$ & $17.6 \pm 15.5(10)$ \\
2-19 May & 50 & $6.5 \pm 2.0(10)$ & $4.7 \pm 0.7(10)$ & $48.2 \pm 8.8(10)$ & $29.2 \pm 26.3(10)$ \\
& 100 & $9.4 \pm 2.8(10)$ & $10.9 \pm 2.9(10)$ & $188.8 \pm 39.1(10)$ & $9.1 \pm 5.4(10)$ \\
Post bloom & 20 & $8.4 \pm 2.8(6)$ & $3.0 \pm 1.2(6)$ & $85.3 \pm 20.0(6)$ & $13.2 \pm 5.6(6)$ \\
28 May-9 June & 50 & $5.3 \pm 3.1(6)$ & $3.8 \pm 1.7(6)$ & $140.0 \pm 12.0(6)$ & $2.8 \pm 1.2(6)$ \\
& 100 & $6.9 \pm 2.1(6)$ & $10.0 \pm 5.6(6)$ & $321.7 \pm 104.5(6)$ & $6.3 \pm 3.9(6)$ \\
\hline
\end{tabular}

tions during the decaying bloom $(\mathrm{p}<0.01, \mathrm{n}=25)$. During the post bloom, the estimate from the in situ faecal pellet production was significantly higher than the other methods (except the egg production $[\mathrm{p}<0.01, \mathrm{n}=$ 9]). The overall averaged grazing rates were significantly lowest in the post-bloom phase $(\mathrm{p}<0.01, \mathrm{n}=13)$.

Quantification of the daily grazing impact of the copepod community on the phytoplankton based on only daytime measurements of gut fluorescence and in situ faecal pellet production requires knowledge about diel feeding periodicity and vertical migration. During the investigation of vertical migration (Fig. 11) we measured gut fluorescence and in situ faecal pellet production at 12:00 and 24:00 h (Table 5), and no significant diurnal differences in these rates were detected. However, the biomass of copepods in the upper $50 \mathrm{~m}$ doubled from our normal sampling time to around 24:00 h, from 1455 \pm 853 to $3147 \pm 1168 \mathrm{mg} \mathrm{C} \mathrm{m}^{-2}$ (Fig. 11) due to vertical migration from deeper layers (data not shown). Consequently, our estimates of grazing impact by the copepod are conservative by not considering the increase in biomass around 24:00 h, and the actual grazing impact could be twice as high as our estimates (Table 2).

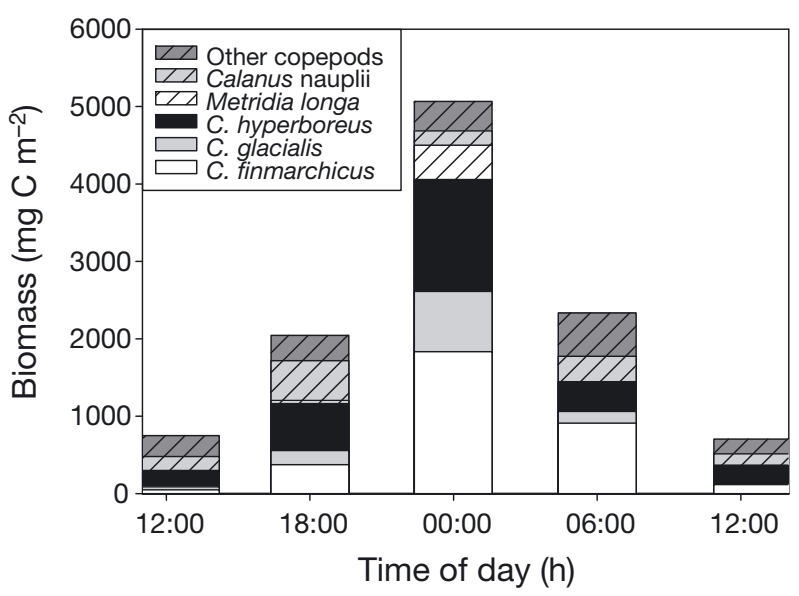

Fig. 11. Average biomass of copepods $\left(\mathrm{mg} \mathrm{C} \mathrm{m}^{-2}\right)$ in the upper $50 \mathrm{~m}$ during a diurnal study from 29 to 30 April

\section{DISCUSSION}

\section{Hydrography and plankton succession}

In Disko Bay, the sea ice conditions are highly variable (Hansen et al. 2003). In some years, no stable sea ice establishes (Madsen et al. 2008b), while in other years, the sea ice breaks up as late as June (Nielsen \& Hansen 1995). In the present study, the sea ice broke up in early April. The spring phytoplankton bloom developed immediately after the breakup of sea ice. Thus, sea ice conditions are very important for the match between the arrival of overwintering copepods to the surface layers and the high spring phytoplankton production, and therefore also for the subsequent sedimentation.

In 2008 the bloom started on 9 April, and the main bloom event (from 23 April) was triggered by a thermocline at $60 \mathrm{~m}$ combined with increasing irradiance. Chl a concentration was in the same order of magnitude as previously reported from a shallow cove of Disko Bay (Sejr et al. 2007). It was, however, nearly twice as high as previously recorded spring concentrations from the Disko Bay proper (Levinsen et al. 2000a, Madsen et al. 2001). Generally the $3 \mathrm{chl}$ a fractions in this study contributed equally to the phytoplankton biomass. However, distinct underlying successions were observed. Prior to the spring bloom chl $a<10 \mu \mathrm{m}$

Table 5. Comparison of gut pigment contents $\left(\mathrm{GC}_{\boldsymbol{i}} \mathrm{ng}\right.$ total pigment $\mathrm{fem}^{-1}$ ) of Calanus spp. and the specific egestion rate $\left(\% \mathrm{~d}^{-1}\right)$ of the copepod community from the in situ fecal pellet experiment around 12:00 h (29 April) and 24:00 h (30 April). Data are averages \pm SE. No. of samples given in parentheses

\begin{tabular}{|lcc|}
\hline & $12: 00 \mathrm{~h}$ & $24: 00 \mathrm{~h}$ \\
\hline Calanus finmarchicus (GC) & $40 \pm 6(8)$ & $31 \pm 9(5)$ \\
C. glacialis (GC) & $60 \pm 10(8)$ & $89 \pm 28(5)$ \\
C. hyperboreus (GC) & $157 \pm 20(20)$ & $204 \pm 24(10)$ \\
Specific egestion rate & $1.0 \pm 0.3(13)$ & $0.8 \pm 0.2(8)$ \\
\hline
\end{tabular}


dominated; during the spring bloom a succession of the 3 size classes was observed initiated by a peak of chl a $<10 \mu \mathrm{m}$, followed by a $10-50 \mu \mathrm{m}$ peak and culminating with a peak of chl $a>50 \mu \mathrm{m}$ (diatoms) and a post-bloom dominance of chl $a<10 \mu \mathrm{m}$ (haptophytes). The same succession was observed throughout the water column. The spring bloom lasted for approximately $1 \mathrm{wk}$ after nitrate depletion. During the second half of May, melt water from glaciers reduced sea surface salinity and the upper $20 \mathrm{~m}$ became additionally stratified. At the end of the investigation chl a concentration was low in the surface, and the phytoplankton were concentrated at the nutricline/pycnocline.

Generally, the timing of the ascending copepods appears to match the spring bloom (Diel \& Tande 1992), which was also confirmed by the present study, where Calanus spp. were present in the surface from the initiation of the bloom. Early appearances of $\mathrm{Ca}$ lanus in April have been observed in Disko Bay in 1996 and 1997 (Madsen et al. 2001) and in 2005 (Madsen et al. 2008b). However, the main difference between the present study and the 2 latter was the higher biomass of Calanus observed already in April and an early maximum biomass peak in early May. It has been suggested that previously sampling of the copepod community with large mesh size nets (e.g. $200 \mu \mathrm{m}$ ) has lead to overestimation of the importance of large species like Calanus. We sampled the copepod community with small mesh size nets $(50 \mu \mathrm{m})$, and still species of Calanus comprised up to $99 \%$ of the biomass, which is typical for Arctic areas during spring (Hirche 1991, Riser et al. 2007, Madsen et al. 2008a,b). The copepods remained abundant in the upper $100 \mathrm{~m}$ throughout the study and did not decrease until early July. C. hyperboreus was the only species observed descending to deep waters, whereas C. finmarchicus and C. glacialis disappeared from the surface but did not aggregate above the bottom as did C. hyperboreus. It is possible that they have dispersed out into the bay proper by deeper currents (Holland et al. 2008). This observation is in contrast to the suggestion of a self-sustaining population of $C$. finmarchicus and C. glacialis in this area as suggested earlier (Madsen et al. 2001, Niehoff et al. 2002).

\section{Seasonal variability of sedimentation in Disko Bay}

During the present study, the sedimentation of organic material increased considerably for all the measured variables. High sedimentation of particulate organic material linked to spring phytoplankton production is common in Disko Bay (Juul-Pedersen et al. 2006, Sejr et al. 2007) and in other Arctic areas (Wassmann 1990, Andreassen et al. 1999, Turner 2002). The
POC sedimentation reported in the present study is, to our knowledge, among the highest reported values during an Arctic spring bloom. It resembles estimates from the spring bloom in a shallow cove in Disko Bay in April (ranging from 1200 to $3000 \mathrm{mg} \mathrm{C} \mathrm{m}^{-2} \mathrm{~d}^{-1}$ in the upper 5 to $45 \mathrm{~m}$; Sejr et al. 2007), but with a substantial higher PPC fraction of the POC (60\% as opposed to $36 \%$ ), despite the same level of phytoplankton biomass in that study. Sejr et al. (2007) suggested a mismatch between ascending copepods and the spring phytoplankton bloom leads to subsequent low grazing impact by the copepods. In addition, the carbon to chl a conversion factor for the sedimented phytoplankton used here was $50 \%$ lower, which implies that our PPC contribution to POC could have been $50 \%$ higher. Sedimentation of PPC has been reported in similar ranges to ours, during a spring bloom in the central Barents Sea in May-June (Olli et al. 2002, Caron et al. 2004, Reigstad et al. 2008). These studies revealed a close coupling between phytoplankton succession and sedimentation as suggested in the present study. Furthermore, our results of POC sedimentation in the post bloom resembled the values previously found in Disko Bay in June (Juul-Pedersen et al. 2006) and in the central Barents Sea in May (Wassmann et al. 1990, Andreassen \& Wassmann 1998). In agreement with the present study, the latter examples report a low contribution of phytoplankton sedimentation relative to carbon in May-June.

Sedimented POC in the present study differed remarkably in composition between two of the bloom phases (developing and post bloom). The above results indicate that much of the vertical reduction (i.e. vertical attenuation) of the settling organic material takes place over a short vertical distance (Fig. 9). The vertical attenuation seems strongest in the upper $50 \mathrm{~m}$, as reported earlier (Riser et al. 2002, Reigstad et al. 2008). The vertical attenuation in the developing bloom of POC was mirrored by amorphous detritus and, to a lesser extent, PPC and FPC. This suggests a selective attenuation of particles where low density particles are being retained above the pycnocline. It is supported by the general lower velocity of PPC in the upper $50 \mathrm{~m}$ relative to $100 \mathrm{~m}$ depth. This is in contrast to the much higher velocities of the denser faecal pellets observed throughout the water column. If the pycnocline is acting as a barrier to the sedimentation of certain particles, the vertical changes of sedimentation rate would not directly reflect the transformation of the sinking material with depth but rather a differential sedimentation of particles.

In the present study, average FPC contribution to sedimenting POC was low $(16 \%)$ but within values reported for the Arctic areas in March-May (Wassmann et al. 1999, Riser et al. 2002) and in June 
(Andreassen et al. 1996). The relative importance of FPC sedimentation is dependent on copepod abundance, FPR, and faecal pellet size (Besiktepe \& Dam 2002, Turner 2002). In the present study, the highest FPC sedimentation was found during the decaying bloom, which is in accordance with the highest FPR (Fig. 7A) and copepod abundance measured.

Nitrogen has previously been shown to be limiting the spring bloom in Disko Bay (Andersen 1981, Nielsen \& Hansen 1995, Juul-Pedersen et al. 2006). When nitrate deficiency in phytoplankton growth occurs, an increase in the POC/PON ratio of 6.6 can be expected (Redfield et al. 1963). The high PPC sedimentation during the bloom was probably caused by nitrate limitations, as nitrate decreased in the photic zone (Fig. 2), although average POC/PON ratios found in the suspended and sedimented material were still close to the Redfield ratio. It is likely that phytoplankton aggregation and density dependent coagulation during growth caused the high sedimentation rate (Kiørboe et al. 1994). This is supported by the increased velocity observed at $100 \mathrm{~m}$ depth and indicates a depth-related formation of phytoplankton aggregates. During the second half of the decaying bloom, decreased phytoplankton biomass and nitrate depletion led to lower POC sedimentation. PPC attenuation was not observed in the upper $50 \mathrm{~m}$, which suggests that the subsurface bloom was located below the pycnocline and depth of mixing. A majority of the sedimented POC (80\%) from the upper $50 \mathrm{~m}$ was found at $100 \mathrm{~m}$, thus supporting this notion. Consequently, sedimentation occurs with reduced resuspension and density dependent particle restrictions though the pycnocline. A post-bloom increase of POC sedimentation coincided with a subsurface phytoplankton bloom supported by reintroduced nitrate. The vertical attenuation of POC fractions resembled that observed in the bloom-developing phase. When nitrate was depleted, at the end of the postbloom phase, both suspended and sedimented POC/ PON ratios increased with depth. Phytoplankton growth was probably nitrate-limited, as indicated by POC/PON ratios well above the Redfield ratio in the sedimented material. We cannot, however, exclude a potential influence of increased carbon concentrations from sedimentation of amorphous detritus and faecal pellets, which would increase the POC/PON ratio (Olesen \& Lundsgaard 1995, Daly 1996, Daly et al. 1999). Furthermore, potential size dependent sedimentation of phytoplankton (Bienfang 1980, Sarthou et al. 2005) or aggregation (Kiørboe \& Hansen 1993, Kiørboe et al. 1994) is not accounted for, which would increase the POC/PON ratio (Olli et al. 2002). The relations between suspended and sedimented carbon and chl a were not significantly different $(\mathrm{p}>0.01, \mathrm{n}=152)$, and the carbon concentration of suspended phyto- plankton relative to the sedimented biomass did not change. Sedimented POC/PON ratios found in Greenland Sea in June-August consisting of nutrient deficient diatoms (Daly et al. 1999) resembled the findings of the present study. Accordingly, we did not find any correlation between nitrate concentration and sedimented POC/PON ratios.

The high sedimentations reported here underline the importance of the process as a path of carbon transport in Disko Bay. The results indicate a seasonal variability in magnitude and composition of POC sedimentation, where fresh phytoplankton sedimented in the developing bloom and the quality and quantity of the sedimented material decreased towards the postbloom phase.

\section{Grazing impact of the copepod community - a comparison of methods}

The seasonal variation in composition, biomass, and feeding activity of the copepods strongly influenced the bentho-pelagic coupling by shaping the quality and quantity of organic material sinking to the depths. The timing of mesozooplankton migration to match the spring phytoplankton bloom is essential for an efficient pelagic turnover of phytoplankton and for the magnitude of the secondary production (Diel \& Tande 1992, Niehoff et al. 2002). Here we applied 4 methods to quantify the grazing impact on the phytoplankton community. The reliability of the measurements depended on season (i.e. the quantitative and qualitative composition of the prey plankton community). The gut fluorescence method directly quantifies the amount of phytoplankton ingested, while pellet and egg production rates through the application of different conversion factors estimate the carbon ingested (i.e. both autotrophic and heterotrophic prey). In addition, the rates are impacted by diel periodicity in feeding and migration. In the present study, no differences could be detected between midday and midnight rate measurements (Table 5), but significant vertical migration took place increasing the night biomass in the upper $50 \mathrm{~m}$. Consequently, our estimated grazing impact could be higher than reported here (Table 2) based on our normal sampling program.

Ingestion calculated from the egg production rate assumes a direct transfer of the ingested food to egg production. This is not always true for copepods that store large amounts of lipids like Calanus (Lee et al. 2006 and references therein). Before the bloom, at low food availability, they may start to produce eggs based on stored lipids (Hirche \& Kattner 1993, Hirche \& Niehoff 1996). At the termination of the bloom, egg production ceases for C. glacialis, as the lipid stores 
are refueled (S. Kjellerup et al. unpubl.). During the bloom, however, the assumption of egg production depending on food availability holds true for the 2 smallest Calanus spp. (Nielsen \& Hansen 1995).

In contrast to egg production, faecal pellet production is more directly related to ingestion (Besiktepe \& Dam 2002, Seuthe et al. 2007). Hence, lower faecal pellet production was measured during the developing bloom than later in the bloom where more food was available. The individual faecal pellet production of the 3 Calanus species was measured in incubations of 24 to $48 \mathrm{~h}$, and there were indications of chl a depletion in the incubation bottles in the post-bloom phase (R. Swalethorp et al. unpubl.) leading to underestimations of the faecal pellet production. Another potential problem is ingestion of faecal pellets during the incubation (coprophagy), as no mesh false bottom was used. However, experiments with Calanus finmarchicus have showed that faecal pellets were fragmented (coprorhexy) rather than ingested (Noji et al. 1991). Faecal pellet loss due to coprophagy might be unimportant in the present study, but if coprorhexy disintegrate the faecal pellets completely (Lampitt et al. 1990, Noji et al. 1991) the result would be an underestimated faecal pellet production. The in situ faecal pellet production experiment measures the instantaneous faecal pellet production in short time incubations, where coprophagy and food limitation should be of minor importance. Another difference to the bottle experiments was that the in situ incubations were made on a mixture of the larger stages (i.e. including copepodites) of the dominating copepods. The smaller copepodites will, on average, have a higher specific pellet production than the adult females (Hansen et al. 1997). Accordingly, the in situ pellet production was consequently higher than the faecal pellet production from the long-duration bottle incubation (Table 2).

The gut fluorescence method gave the highest grazing estimate of all the methods during the first 2 bloom phases, mainly as a result of a high specific production by Calanus finmarchicus, approximately $60 \%$ higher than estimated for C. glacialis and C. hyperboreus. During the 2 first bloom phases the potential food was completely dominated by diatoms. In such situations, the gut fluorescence method can therefore be expected to produce very reliable estimates of copepod grazing. During the post-bloom phase, the highest estimates came from the in situ production. Gut fluorescence may underestimate the grazing rate when phytoplankton biomass is low and/or dominated by small spp., since copepods then ingest non-fluorescent food particles such as protozooplankton to sustain production (Ohman \& Runge 1994, Hirche \& Kwasniewski 1997, Hansen et al. 1999, Levinsen et al. 2000b). Consequently, successful application of the gut fluorescence method is restricted to phases when herbivory dominates, i.e. during the spring phytoplankton bloom (Kiørboe et al. 1985, Peterson et al. 1990). Thus, a direct correlation between mixed food availability and faecal pellet production seemed to give the most reliable value from the in situ production during the postbloom phase.

The 2 faecal pellet production estimate methods based on direct counting are much more time-consuming than gut fluorescence, but they are a much more reliable tool for estimating the grazing throughout the season. Furthermore, the in situ faecal pellet production reduces potential coprophagy and coprorhexy on produced faecal pellets by separating copepods and their pellets. In addition, a short-term incubation period minimized the risk of food depletion during incubation. In contrast, during a long-term experiment, a loss of phytoplankton due to sedimentation and/or grazing during the incubation period can lead to negative effects on the faecal pellet production over time (Besiktepe \& Dam 2002, Seuthe et al. 2007), but the long duration is nonetheless necessary when measuring egg production of batch spawning copepods.

In summary, all 4 methods have their strengths and limitations. The choice of method depends on the season, i.e. condition and composition of the phytoplankton community as well as the specific research objective and the time available. Here the overall average was applied to evaluate the copepod community grazing impact on phytoplankton (Fig. 10). Despite a match between the developing bloom and the arrival of Calanus to the surface layer, the grazing impact of the copepods was insignificant in the termination of the spring bloom (Table 1, Fig. 10).

The short exponential spring phytoplankton bloom in Disko Bay in 2008 resulted in high phytoplankton sedimentation. The 4 methods used to evaluate the copepod grazing potential concurrently show that grazing impact by copepods played a minor role on the observed phytoplankton succession. Therefore the termination of the phytoplankton spring bloom was primarily caused by sedimentation of nitrogen-limited phytoplankton rather than grazing from the Calanusdominated copepod community.

Acknowledgements. This study was financed by the National Environmental Research Institute (NERI), Aarhus University, Roskilde University (RU), Carlsberg Foundation, Oticon Foundation, ECOGREEN, the Danish Natural Sciences Research Council, and the University of Southern Denmark (SDU). We thank the Arctic station in Qeqertarsuaq and the scientific leader Outi Maria Tervo, University of Copenhagen, who provided us with excellent laboratory facilities and logistical support. At sea, MS 'Porsild' and crew, and captain Finn Steffensen on RV 'Maja S.' with crew provided a great working platform. Also we greatly acknowledge Birgit Søborg in her logistical and technical support. 


\section{LITERATURE CITED}

Andersen OGN (1981) The annual cycle of phytoplankton, primary production and hydrography in the Disko Bay area, West Greenland. Medd Gronl Biosci 6:1-65

> Andreassen IJ, Wassmann P (1998) Vertical flux of phytoplankton and particulate biogenic matter in the marginal ice zone of the Barents Sea in May 1993. Mar Ecol Prog Ser 170:1-14

Andreassen I, Nothig EM, Wassmann P (1996) Vertical particle flux on the shelf off northern Spitsbergen, Norway. Mar Ecol Prog Ser 137:215-228

Andreassen IJ, Wassmann P, Ratkova TN (1999) Seasonal variation of vertical flux of phytoplankton and biogenic matter at Nordvestbanken, north Norwegian shelf in 1994. Sarsia 84:227-238

Bathmann UV, Noji TT, Vonbodungen B (1990) Copepod grazing potential in late winter in the Norwegian Sea - a factor in the control of spring phytoplankton growth. Mar Ecol Prog Ser 60:225-233

Besiktepe S, Dam HG (2002) Coupling of ingestion and defecation as a function of diet in the calanoid copepod Acartia tonsa. Mar Ecol Prog Ser 229:151-164

Bienfang PK (1980) Phytoplankton sinking rates in oligotrophic waters of Hawaii, USA. Mar Biol 61:69-77

Caron G, Michel C, Gosselin M (2004) Seasonal contributions of phytoplankton and fecal pellets to the organic carbon sinking flux in the North Water (northern Baffin Bay). Mar Ecol Prog Ser 283:1-13

Conover RJ (1966) Factors affecting assimilation of organic matter by zooplankton and question of superfluous feeding. Limnol Oceanog 11:346-354

Daly KL (1996) Flux of particulate matter through copepods in the Northeast Water Polynya, Helsingør, Denmark, p 319-342

Daly KL, Wallace DWR, Smith WO, Skoog A and others (1999) Non-Redfield carbon and nitrogen cycling in the Arctic: effects of ecosystem structure and dynamics. J Geophys Res Ocean 104:3185-3199

> De La Rocha CL, Passow U (2007) Factors influencing the sinking of POC and the efficiency of the biological carbon pump. Deep-Sea Res II 54:639-658

Diel S, Tande K (1992) Does the spawning of Calanus finmarchicus in high-latitudes follow a reproducible pattern. Mar Biol 113:21-31

Grasshoff K (1976) Methods for seawater analysis. Weinheim, New York

> Hansen B, Berggreen UC, Tande KS, Eilertsen HC (1990) Post-bloom grazing by Calanus glacialis, C. finmarchicus and C. hyperboreus in the region of the Polar Front, Barents Sea. Mar Biol 104:5-14

> Hansen PJ, Bjørnsen PK, Hansen BW (1997) Zooplankton grazing and growth: Scaling within the $2-2,000-\mu \mathrm{m}$ body size range. Limnol Oceanogr 42:687-704

> Hansen BW, Nielsen TG, Levinsen H (1999) Plankton community structure and carbon cycling on the western coast of Greenland during the stratified summer situation. III. Mesozooplankton. Aquat Microb Ecol 16:233-249

Hansen BW, Marker T, Andreassen P, Arashkewich E and others (2003) Differences in life-cycle traits of Calanus finmarchicus originating from $60^{\circ} \mathrm{N}$ and $69^{\circ} \mathrm{N}$, when reared in mesocosms at $69^{\circ} \mathrm{N}$. Mar Biol 142:877-893

Harris RP, Wiebe PH, Lenz J, Skjoldal HR, Huntley M (2000) ICES zooplankton methodology manual. Academic Press, London

> Hirche HJ (1991) Distribution of dominant Calanoid copepod species in the Greenland Sea during late fall. Polar Biol
11:351-362

> Hirche HJ, Kattner G (1993) Egg production and lipid content of Calanus glacialis in spring: indication of a food-dependent and food-independent reproductive mode. Mar Biol 117:615-622

Hirche HJ, Kwasniewski S (1997) Distribution, reproduction and development of Calanus species in the Northeast Water in relation to environmental conditions. Elsevier Science, Helsingør, p 299-317

Hirche HJ, Niehoff B (1996) Reproduction of the Arctic copepod Calanus hyperboreus in the Greenland Sea, field and laboratory observations. Polar Biol 16:209-219

Holland DM, Thomas RH, De Young B, Ribergaard MH, Lyberth B (2008) Acceleration of Jakobshavn Isbræ triggered by warm subsurface ocean waters. Nature Geosci 1:659-664

Jespersen AM, Christoffersen K (1987) Measurements of chlorophyll-a from phytoplankton using ethanol as extraction solvent. Arch Hydrobiol 109:445-454

Juul-Pedersen T, Nielsen TG, Michel C, Møller EF and others (2006) Sedimentation following the spring bloom in Disko Bay, West Greenland, with special emphasis on the role of copepods. Mar Ecol Prog Ser 314:239-255

Kiørboe T (1998) Population regulation and role of mesozooplankton in shaping marine pelagic food webs. Kluwer Academic, Helsinki, p 13-27

Kiørboe T, Hansen JLS (1993) Phytoplankton aggregate formation - observations of patterns and mehanisms of cell sticking and the significance of exopolymeric material. J Plankton Res 15:993-1018

Kiørboe T, Møhlenberg F, Riisgård HU (1985) In situ feeding rates of plantonic copepods: a comparison of four methods. J Exp Mar Biol Ecol 88:67-81

Kiørboe T, Lundsgaard C, Olesen M, Hansen JLS (1994) Aggregation and sedimentation processes during a spring phytoplankton bloom - a field experiment to test coagulation theory. J Mar Res 52:297-323

Kiørboe T, Hansen JLS, Alldredge AL, Jackson GA and others (1996) Sedimentation of phytoplankton during a diatom bloom: rates and mechanisms. J Mar Res 54:1123-1148

Knap A, Michaels A, Close A, Ducklow H, Dickson H (1996) Protocols for the Joint Global Ocean Flux Study (JGOFS) core measurements. Report no. 19, Reprint of the IOC Manuals and Guides no. 29, UNESCO, Bergen

Lampitt RS, Noji T, Vonbodungen B (1990) What happens to zooplankton fecal pellets - implication for material flux. Mar Biol 104:15-23

> Lee RF, Hagen W, Kattner G (2006) Lipid storage in marine zooplankton. Mar Ecol Prog Ser 307:273-306

Levinsen H, Nielsen TG, Hansen BW (2000a) Annual succession of marine pelagic protozoans in Disko Bay, West Greenland, with emphasis on winter dynamics. Mar Ecol Prog Ser 206:119-134

Levinsen H, Turner JT, Nielsen TG, Hansen BW (2000b) On the trophic coupling between protists and copepods in arctic marine ecosystems. Mar Ecol Prog Ser 204:65-77

Maar M, Nielsen TG, Richardson K, Christaki U, Hansen OS, Zervoudaki S, Christou ED (2002) Spatial and temporal variability of food web structure during the spring bloom in the Skagerrak. Mar Ecol Prog Ser 239:11-29

Madsen SD, Nielsen TG, Hansen BW (2001) Annual population development and production by Calanus finmarchicus, C. glacialis and C. hyperboreus in Disko Bay, western Greenland. Mar Biol 139:75-93

> Madsen SD, Nielsen TG, Hansen BW (2008a) Annual population development and production by small copepods in Disko Bay, western Greenland. Mar Biol 155:63-77

Madsen SJ, Nielsen TG, Tervo OM, Söderkvist J (2008b) 
Importance of feeding for egg production in Calanus finmarchicus and C. glacialis during the Arctic spring. Mar Ecol Prog Ser 353:177-190

Niehoff B, Madsen S, Hansen B, Nielsen T (2002) Reproductive cycles of three dominant Calanus species in Disko Bay, West Greenland. Mar Biol 140:567-576

> Nielsen TG, Hansen B (1995) Plankton community structure and carbon cycling on the western coast of Greenland during and after the sedimentation of a diatom bloom. Mar Ecol Prog Ser 125:239-257

Noji TT, Estep KW, Macintyre F, Norrbin F (1991) Imageanalysis of fecal material grazed upon by 3 species of copepods-evidence for coprorhexy, coprophagy and coprochaly. J Mar Biol Assoc UK 71:465-480

Ohman MD, Runge JA (1994) Sustained fecundity when phytoplankton resources are in short supply - omnivory by Calanus finmarchicus in the Gulf of St. Lawrence. Limnol Oceanogr 39:21-36

Olesen M, Lundsgaard C (1995) Seasonal sedimentation of autochthonous material from the euphotic zone of a coastal system. Estuar Coast Shelf Sci 41:475-490

Olli K, Riser CW, Wassmann P, Ratkova T, Arashkevich E, Pasternak A (2002) Seasonal variation in vertical flux of biogenic matter in the marginal ice zone and the central Barents Sea. J Mar Syst 38:189-204

Peterson W, Painting S, Barlow R (1990) Feeding rates of Calanoides carinatus - a comparison of five methods including evaluation of the gut fluorescence method. Mar Ecol Prog Ser 63:85-92

Poulsen LK, Reuss N (2002) The plankton community on Sukkertop and Fylla Banks off west Greenland during a spring bloom and post-bloom period: hydrography, phytoplankton and protozooplankton. Ophelia 56:69-85

Redfield AC, Ketchum BH, Richards FA (1963) The influence of organisms on the composition of seawater. In: Hill MN (ed) The sea, Vol 2. Wiley-Interscience, New York, p 6-77

Reigstad M, Riser CW, Wassmann P, Ratkova T (2008) Vertical export of particulate organic carbon: attenuation, composition and loss rates in the northern Barents Sea. DeepSea Res II 55:2308-2319

Riser CW, Wassmann P, Olli K, Pasternak A, Arashkevich E (2002) Seasonal variation in production, retention and export of zooplankton faecal pellets in the marginal ice zone and central Barents Sea. J Mar Syst 38:175-188

Riser CW, Reigstad M, Wassmann P, Arashkevich E, FalkPetersen S (2007) Export or retention? Copepod abundance, faecal pellet production and vertical flux in the marginal ice zone through snap shots from the northern Barents Sea. Polar Biol 30:719-730

Editorial responsibility: Hans Heinrich Janssen, Oldendorf/Luhe, Germany
Riser CW, Wassmann P, Reigstad M, Seuthe L (2008) Vertical flux regulation by zooplankton in the northern Barents Sea during Arctic spring. Deep-Sea Res II 55:2320-2329

Sarthou G, Timmermans KR, Blain S, Treguer P (2005) Growth physiology and fate of diatoms in the ocean: a review. J Sea Res 53:25-42

Satapoomin S (1999) Carbon content of some common tropical Andaman Sea copepods. J Plankton Res 21:2117-2123

Sejr MK, Nielsen TG, Rysgaard S, Risgaard-Petersen N, Sturluson M, Blicher ME (2007) Fate of pelagic organic carbon and importance of pelagic-benthic coupling in a shallow cove in Disko Bay, West Greenland. Mar Ecol Prog Ser 341:75-88

> Seuthe L, Darnis G, Riser CW, Wassmann P, Fortier L (2007) Winter-spring feeding and metabolism of Arctic copepods: insights from faecal pellet production and respiration measurements in the southeastern Beaufort Sea. Polar Biol 30:427-436

Thor P, Nielsen TG, Tiselius P, Juul-Pedersen T and others (2005) Post-spring bloom community structure of pelagic copepods in the Disko Bay, western Greenland. J Plankton Res 27:341-356

> Turner JT (2002) Zooplankton fecal pellets, marine snow and sinking phytoplankton blooms. Aquat Microb Ecol 27: 57-102

Wassmann P (1990) Relationship between primary and export production in the boreal coastal zone of the north-Atlantic. Limnol Oceanogr 35:464-471

- Wassmann P (1998) Retention versus export food chains: processes controlling sinking loss from marine pelagic systems. Hydrobiologia 363:29-57

- Wassmann P, Vernet M, Mitchell BG, Rey F (1990) Mass sedimentation of Phaeocystis pouchetii in the Barents Sea. Mar Ecol Prog Ser 66:183-195

Wassmann P, Hansen L, Andreassen IJ, Riser CW, Urban-Rich J (1999) Distribution and sedimentation of faecal pellets on the Nordvestbanken shelf, northern Norway, in 1994. Sarsia 84:239-252

Wassmann P, Bauerfeind E, Fortier M, Fukuchi M and others (2004) Particulate organic carbon flux to the Arctic Ocean sea floor. In: Stein R, Macdonald RW (eds) The organic carbon cycle in the Arctic Ocean. Springer Verlag, Berlin, p 101-138

Wassmann P, Reigstad M, Haug T, Rudels B and others (2006) Food webs and carbon flux in the Barents Sea. Prog Oceanogr 71:232-287

Yentsch CS, Menzel DW (1963) A method for the determination of phytoplankton chlorophyll and phaeophytin by fluorescence. Deep-Sea Res 10:221-231

Submitted: October 19, 2009; Accepted: September 7, 2010 Proofs received from author(s): November 1, 2010 